Review

\title{
The Health Effects of Climate Change in the WHO European Region
}

\author{
Tanja Wolf ${ }^{1, *}$, Katrina Lyne ${ }^{2}$, Gerardo Sanchez Martinez ${ }^{1}$ and Vladimir Kendrovski ${ }^{1}$ \\ 1 WHO European Centre for Environment and Health, Platz der Vereinten Nationen 1, \\ Bonn 53113, Germany; E-Mails: sanchezmartinezg@ecehbonn.euro.who.int (G.S.M.); \\ kendrovskiv@ecehbonn.euro.who.int (V.K.) \\ 2 Consultant to WHO European Centre for Environment and Health, Platz der Vereinten Nationen 1, \\ Bonn 53113, Germany; E-Mail: katrina.lyne@gmail.com \\ * Author to whom correspondence should be addressed; E-Mail: wolft@who.int; \\ Tel.: +49-228-815-0425.
}

Academic Editor: Alessandro Pezzoli

Received: 30 June 2015 / Accepted: 29 October 2015 / Published: 16 November 2015

\begin{abstract}
The evidence of observed health effects as well as projections of future health risks from climate variability and climate change is growing. This article summarizes new knowledge on these health risks generated since the IPCC fourth assessment report (AR4) was published in 2007, with a specific focus on the 53 countries comprising the WHO European Region. Many studies on the effects of weather, climate variability, and climate change on health in the European Region have been published since 2007, increasing the level of certainty with regard to already known health threats. Exposures to temperature extremes, floods, storms, and wildfires have effects on cardiovascular and respiratory health. Climate- and weather-related health risks from worsening food and water safety and security, poor air quality, and ultraviolet radiation exposure as well as increasing allergic diseases, vector- and rodent-borne diseases, and other climate-sensitive health outcomes also warrant attention and policy action to protect human health.
\end{abstract}

Keywords: climate; climate change; climate variability; weather; health; diseases; literature; heat; cold; air pollution; ultraviolet radiation; allergies; flood; vectors 


\section{Introduction}

As all over the world, the climate in the 53 countries comprising the WHO European Region is changing [1]. Temperatures are increasing, as are the frequency and intensity of extreme weather events including heatwaves, floods, and wildfires, and these trends are projected to continue under the most likely climate change scenarios [2]. Climate change affects health via direct and indirect pathways. Direct health effects of climate change include those attributable to extremes of temperature, extreme weather events, and exposure to ultraviolet radiation. Indirect effects include those mediated through either natural or human systems, such as patterns of certain vector-borne infectious diseases, respiratory diseases from changes in air quality and allergens, diarrheal disease, malnutrition and stunting from worsening food, and water safety and security. The health outcomes attributable to climate include premature mortality, several communicable and noncommunicable diseases, mental health issues, and effects on occupational health, nutrition, and social function [3]. It is predicted that the net effects of climate change on health, in Europe and worldwide, will be negative [3-5].

Certain groups are particularly vulnerable to the health effects of climate change, including the elderly, children, people with chronic diseases, people from low income groups, and workers subject to specific exposure (such as extreme temperatures, fires, and flooding). In addition, the increasing burden of climate change on human health will generate new and growing challenges for health systems, due to increases in care demands relating to increased morbidity and mortality, and additional pressure from extreme weather events. This will generate costs for all of society and exacerbate inequality [6]. Opportunities to both mitigate climate change and protect health have received increasing attention in recent years $[7,8]$. Countries across the WHO European Region have varying capacities to assess the health effects of climate change $[9,10]$. This literature review provides an update on observations and projections for various climate change-related health effects in the WHO European Region from 2007 through 2014.

\section{Methods}

A comprehensive literature search was conducted according to the Preferred Reporting Items for Systematic Reviews and Meta-Analyses (PRISMA) methodology [11]. The search was designed to identify recent research papers relevant to the effects of climate change on health in the WHO European Region. We searched for studies on climate change and health using the PubMed and ScienceDirect databases from January 2007 to 5 September 2014.

Four search algorithms were designed for use in the PubMed and ScienceDirect databases, allowing a basic search as well as searches specific to different health outcomes and risks. The algorithms used incorporate three main elements: country names, climate (exposure), and health effect/s (outcome/s). Countries included the 53 WHO European Region Member States (http://www.euro.who.int/en/ countries) as well as the keywords Europe and central Asia.

Original research papers were identified, with further material obtained by way of screening the references of identified papers. The reference lists of selected key papers were also reviewed, and relevant citations obtained from the aforementioned scientific databases. Additionally, the website of the 
European Commission Community Research and Development Information Service (CORDIS) was used to identify relevant European Commission-funded projects and publications [12].

All identified studies assessing the effects, observed or projected, of climate-related impacts on health in Europe were considered for inclusion in this review. Studies were limited to those published in English from 2007 onwards. Owing to the diverse scale of potential climate-related health effects, considered studies included those assessing health effects dependent on long-term climate change as well as those caused by more acute weather and climate variables, such as extreme weather events.

After screening, identified original research papers were assessed by topic and reference lists and summary tables outlining the characteristics of each study were compiled. To avoid assessor bias, the results of this search were cross-checked with those of a previous, preliminary search performed on 19 January 2014 using the same algorithms and methodology. Significant sources of bias were not identified. A reference management program (Mendeley Desktop 1.13.3 ${ }^{\circledR}$ ) was used to organize and process search results.

\section{Results}

The initial search performed using the four search algorithms in PubMed returned, after removal of duplicates, a total of 6550 results, with an additional 2740 identified using ScienceDirect. First screening (by way of automatic filters in PubMed and manual screening of ScienceDirect search results) returned a total of 631 papers. A second screening applying established eligibility criteria, assessment of abstracts, and assessment of full-text versions excluded another 527 articles. An additional 31 studies were identified via a hand search, leaving a final total of 135 studies included for review (see Figure 1).

The search results were grouped as studies relevant to the direct and indirect health effects of climate change. The direct effects encompass:

- high temperature and heat,

- low temperature and cold,

- floods,

- wildfires, and

- UV radiation.

The indirect effects comprise

- Climate sensitive vector-borne infectious diseases (mosquito-, tick- and rodent-borne),

- Food- and water-related health effects;

- those related to air quality, and

- allergic diseases.

A count and classification of the 135 papers identified in the search by topic are provided in Table 1 . The findings from these studies are presented in the subsequent sections of this review. Due to the large number of papers and the heterogeneity of studies in each topic, very brief and topic-specific summary tables present the search results at the end of each subsection. In addition, the search results are described and explained in a more narrative way. Several review articles and technical, government, and policy documents were used to provide background information to illustrate the relevance of the sub-topics for public health in Europe. 


\begin{tabular}{|c|c|c|}
\hline Identification & 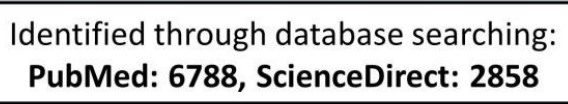 & $\begin{array}{l}\text { Duplicates removed: } \\
\text { PubMed: - 238, ScienceDirect : }-118\end{array}$ \\
\hline 1. Screening & $\begin{array}{l}\text { Subject to first screening: } \\
\text { PubMed: 6550, ScienceDirect : } \mathbf{2 7 4 0}\end{array}$ & $\begin{array}{l}\text { Excluded in first screening: } \\
\text { Pubmed: - 6371, ScienceDirect: } \mathbf{- 2 4 0 6}\end{array}$ \\
\hline 2. Screening & $\begin{array}{l}\text { Total records after first screening: } \\
\qquad 631\end{array}$ & $\begin{array}{l}\text { Excluded in second screening and } \\
\text { assessment of eligibility: } \mathbf{- 5 2 7}\end{array}$ \\
\hline Eligibility & $\begin{array}{l}\text { Studies remaining: } \\
104 \\
\end{array}$ & $\begin{array}{l}\text { Additional records identified by hand } \\
\text { searching: }+\mathbf{3 1}\end{array}$ \\
\hline Included & $\begin{array}{l}\text { Total number of studies: } \\
135\end{array}$ & \\
\hline
\end{tabular}

Figure 1. Flow chart.

Table 1. Screened results of literature search.

\begin{tabular}{llc}
\hline & \multicolumn{1}{c}{ Topic } & Identified Studies \\
\hline & High temperature and heat-wave & 23 \\
& Low temperature and cold & 10 \\
Direct health effects (48) & Floods & 5 \\
& Wildfires & 6 \\
& Ultraviolet radiation & 4 \\
\hline & Vector- (mosquito, tick) and rodent-borne & 37 \\
& infectious diseases & 7 \\
Indirect health effects (87) & Food- and water-related diseases & 26 \\
& Air quality & 17 \\
& Allergic diseases & \\
\hline & \multicolumn{1}{c}{ Total: 135 } \\
\hline
\end{tabular}

\subsection{Direct Health Effects}

\subsubsection{High Temperature and Heatwaves}

Twenty-three papers assessing the health effects of high temperatures and heatwaves were identified in this search. The papers evaluate the health effects, such as morbidity and mortality, caused by extreme summer heat waves as well as the effects of high temperatures.

High temperatures are a threat to human health in Europe. More than 70,000 additional deaths occurred in Europe during hot periods in summer 2003, in comparison to the reference period of 1998-2002 [13]. The combination of extreme daytime maximum temperatures and warm nocturnal temperatures is particularly hazardous [14]. Mortality can be up to three times higher during long, high-intensity heatwaves [15,16]. In Berlin, higher death rates occur in densely built-up areas compared to rural areas [17]. The effect of heatwaves on different populations is highly variable; for example, mortality increased by $7.6 \%$ in Munich compared to 33.6\% in Milan. A greater increase in mortality on 
heatwave days was observed in Mediterranean cities compared with cities in northern parts of Europe (21.8\% and $12.4 \%$ mortality increase, respectively) [15]. In contrast, cities with cooler climates have a greater increase in mortality per $1{ }^{\circ} \mathrm{C}$ increase above a local temperature threshold, compared to warmer cities [18]. A study in Central Italy found that a $1{ }^{\circ} \mathrm{C}$ increase in temperature above a threshold was associated with an increase in mortality of up to $15.97 \%$ among people aged 75 years or more, over a lag period of 30 days [19]. A lag effect is evident for heat- and heatwave-related mortality and morbidity, with the maximum death rate and hospital emergency department presentations occurring two to three days after peak temperature [20-22].

Excess deaths during heatwaves may be caused by dementia, renal disease, respiratory disease, and cerebrovascular disease [13]. Hot periods can lead to dehydration, hyperthermia, renal colic and renal failure [23]. Heatwaves have a significant effect on morbidity and mortality due to respiratory diseases [15]. Each $1{ }^{\circ} \mathrm{C}$ increase in temperature above local comfort thresholds is associated with an average mortality increase of $12 \%$, compared with the daily mean [16]. Furthermore, for each $1{ }^{\circ} \mathrm{C}$ increase above a threshold in maximum apparent temperature, hospital admissions for respiratory disorders increased by up to $4.5 \%$ in 12 European cities [24]. Ambulance dispatches increase for every $1{ }^{\circ} \mathrm{C}$ increase in mean apparent temperature between $25{ }^{\circ} \mathrm{C}$ and $30{ }^{\circ} \mathrm{C}$. The increase is greatest on days when the mean apparent temperature is more than $30^{\circ} \mathrm{C}$, with ambulance dispatches up to $9 \%$ higher on these days [25].

Elderly people are more vulnerable to the effects of heatwaves, due in part to poorer physical health and the effects of cognitive impairment on the perception of heat-related health risk [22]. However, temperature-dependent mortality is also high among young populations, particularly in Eastern and Southern Mediterranean cities including Istanbul and Tel Aviv [18]. Increased summer temperatures also have consequences for pregnancy and preterm birth. The risk of preterm birth increased by up to $20 \%$ when the maximum apparent temperature exceeded the 90 th percentile $\left(36{ }^{\circ} \mathrm{C}\right)$ in the two days prior to delivery. An increase in preterm birth was also observed when the minimum temperature was above the 90th percentile in the week prior to delivery [26].

Summer temperatures, as well as the frequency and severity of heatwaves, are expected to increase in Europe as the climate changes [27]. An increase in the distribution of severe and extreme stress heatwaves is expected in Europe under the SRES A1B scenario, with a northward expansion of affected areas anticipated. Mediterranean countries will be particularly affected by extreme heat events, especially Portugal, Italy, Greece, Turkey, and southern Spain. In these countries, temperatures during severe stress heatwaves may increase by up to $5-7{ }^{\circ} \mathrm{C}$ per heatwave day by $2075-2094$. Other areas may experience temperature increases of up to $4-5{ }^{\circ} \mathrm{C}$ per heatwave day. The frequency and number of severe and extreme heatwave days are expected to increase by up to 45 days per summer by the late 21 st century, and heatwaves may occur both earlier and later in the season, including late spring and early autumn, by 2071-2100 [14]. Highly urbanized areas are projected to be at increased risk from heat stress, compared with surrounding areas [28].

Heat-related mortality is expected to increase. A study across 10 cities in central Italy projects increases in heat-related mortality. The greatest increases are predicted in coastal regions, with mortality expected to increase by up to $11.8 \%$ by $2031-2050$, compared with the baseline for $1999-2008$, for each $1{ }^{\circ} \mathrm{C}$ increase above the estimated temperature threshold [19]. Heat-related hospital admissions for respiratory conditions are predicted to increase as well. The proportion of heat-related admissions is expected to 
approximately double, from $0.18 \%$ in the baseline period (1981-2010) to $0.4 \%$ in the period $2021-2050$. Considering that the number of warm days is also expected to increase, the number of heat-related respiratory hospital admissions is projected to increase from 11,000 per year at baseline to 26,000 per year. The greatest increases are expected in southern European countries, with the proportion of heatrelated admissions for respiratory conditions expected to approximately triple in this region [29].

In Europe, the health burden of heat and heatwaves under climate change conditions will decrease in the short term, as warming is likely to avert 50,000 to 100,000 cold-related deaths by the 2020s [30]. However, by the 2080s, heat-related mortality rates in Europe are likely to increase by $12-33$ per 100,000 per year, totaling approximately 50,000 to 160,000 additional deaths annually. The greatest increase in mortality is expected in central and southern Europe [30]. The costs of an estimated 26,000 additional heat-related deaths per year by the 2020 s, 89,000 by the 2050 s, and 127,000 by the 2080 s, using a A1B scenario without mitigation or adaptation, amount to $€ 147$ billion/year when using the value of statistical life approach [31]. The same study highlights that these impacts can be reduced to a stable 69,000 deaths and $€ 80$ billion per year when the EU's $2{ }^{\circ} \mathrm{C}$ target is adhered to [31].

Table 2 lists the search results by author according to the focus of papers for heatwaves and high temperature: observed mortality, observed morbidity, and projection studies. While most reports about observed mortality or morbidity are related to heatwaves, five studies are about observed mortality or morbidity related to higher temperatures. Four studies assess the future impacts of higher temperature or heat and six studies address multiple or different aspects of this topic.

Table 2. Search results about health effects of extreme heatwaves and high temperature (23).

\begin{tabular}{|c|c|c|}
\hline Health Effect & Related to Extreme Heat & Related to Higher Temperature \\
\hline $\begin{array}{l}\text { Observed } \\
\text { mortality }\end{array}$ & $\begin{array}{l}\text { Extreme temperatures are associated with } \\
\text { increases in mortality }[15-17,22,32]\end{array}$ & $\begin{array}{l}\text { Mortality increases are associated with } \\
\text { temperatures above a local comfort threshold }[13,18]\end{array}$ \\
\hline $\begin{array}{l}\text { Observed } \\
\text { morbidity }\end{array}$ & $\begin{array}{c}\text { Extreme temperature is associated with } \\
\text { increases in morbidity }[20,23,26]\end{array}$ & $\begin{array}{l}\text { Morbidity indicators are associated } \\
\text { with higher temperatures }[24,25,33]\end{array}$ \\
\hline $\begin{array}{c}\text { Future } \\
\text { projection }\end{array}$ & $\begin{array}{c}\text { Future expected extreme temperatures are } \\
\text { expected to increase heat-related mortality [14] } \\
\text { Projected effects of heatwaves and high } \\
\text { temperature have economic costs }[27,30]\end{array}$ & $\begin{array}{l}\text { Future increases in temperature are estimated } \\
\text { to increase health effects of temperatures } \\
\text { above a comfort temperature }[28,29,31,34]\end{array}$ \\
\hline $\begin{array}{l}\text { Other or } \\
\text { multiple focus }\end{array}$ & $\begin{array}{r}\text { There is confounding by air p } \\
\text { Heat and cold, mortality and morbidity, obs } \\
\text { Different population }\end{array}$ & $\begin{array}{l}\text { llution for heat and cold effects [35] } \\
\text { rvation and projection are relevant in Europe [19] } \\
\text { subgroups are at risk [36] }\end{array}$ \\
\hline
\end{tabular}

\subsubsection{Low Temperature and Cold Spells}

Ten papers identified in this search addressed the health effects of low temperatures and cold spells.

Low temperatures and extreme cold weather pose a significant risk to human health. Low temperatures have an effect on respiratory tract infections [37], myocardial infarction [38], stroke hospitalization [39] and general hospital admissions [40], and mortality [35,41-43]. Extreme cold spells cause increases in morbidity [38] and mortality due to respiratory, cardio-, and cerebrovascular diseases [39,44,45]. The effect of cold weather on mortality increases with age, and is greater in warmer (southern) cities. On average, a $1{ }^{\circ} \mathrm{C}$ decrease in daily minimum apparent temperature in seven Mediterranean cities during 
the cold season was associated with a $1.62 \%$ increase in daily total (natural) mortality, and a 2.29\%, $2.80 \%$, and $2.03 \%$ increase in mortality from cardiovascular, respiratory, and cerebrovascular causes, respectively [35]. A lag effect of up to 23 days was observed, particularly for respiratory mortality, highlighting the prolonged effects of cold weather on health [35]. A study performed in Spain found that each $1{ }^{\circ} \mathrm{C}$ decrease below a seasonal temperature threshold caused a mortality excess of $10 \%$ [45]. An association between lower temperatures and mortality due to cancer, respiratory diseases, and cardiovascular diseases was also found. The strongest effect was seen on cancer mortality among the elderly, particularly on days when the temperature was lower than the 5th percentile for the cold season [41].

As the climate warms, cold-related deaths in the European Union are expected to fall by 50,000 to 100,000 deaths per year by the 2020 s and by 100,000 to 250,000 deaths per year by the 2080 s, with Ireland, the United Kingdom, and southern Europe likely to experience the greatest reductions in cold-related mortality [30]. In the short term, a reduction in cold-related mortality may be greater than the expected increase in heat-related mortality; however, over time the reduction in deaths due to cold will likely be insufficient to offset increases in heat-related mortality. A study across 10 cities in central Italy has compared projected heat and cold-related mortality for the period 2031-2050. Cold-related mortality shows a variable change, from $-1.2 \%$ to $0.9 \%$ for each $1{ }^{\circ} \mathrm{C}$ below the estimated cold season temperature threshold. Conversely, in the same region, mortality rates are expected to increase by up to $11.8 \%$ for each $1{ }^{\circ} \mathrm{C}$ increase above the threshold during the warm season [19].

Table 3, [19,30,35,38-46] lists the search results according to the focus of the research. Most of the papers address the observed effects of low temperatures on mortality (4) and morbidity (3). Three papers analyze the effects of extreme cold: two on mortality and one on morbidity. Two papers provide projections of the future impacts of cold in the context of overall assessments of heat and cold.

\subsubsection{Floods}

The search identified only five recent papers that report the health effects of floods. Only one reported observed health effects from flooding (in the Netherlands), while others report on projection studies (see Table 4).

Flooding is a serious risk in the WHO European Region. The International Disaster Database of the Centre for Research on the Epidemiology of Disasters (EmDAT) reports 173 flood events (including coastal, fluvial/riverine, flash, and ice jam flood) between 2007 and 2014 in the countries of the WHO European Region, causing 1078 deaths and affecting more than 5 million people [47]. Episodes of heavy precipitation are likely to increase in Europe in the face of a changing climate. As a result, the risk of flash flood events with subsequent risk of morbidity and mortality is likely to increase in some areas [48]. Water quality could be compromised as a result of heavy rainfall and variability in rainfall and runoff [49]. However, given the unpredictable nature and relative infrequency of flash floods, accurate forecasts are difficult and subject to wide regional variation [50]. 
Table 3. Search results about health effects of low temperature (10).

\begin{tabular}{|c|c|c|}
\hline Health Effect & Low Temperature & Extreme Cold \\
\hline \multirow{4}{*}{$\begin{array}{l}\text { Observed } \\
\text { mortality }\end{array}$} & $\begin{array}{l}\text { Low temperature is associated with observed mortality } \\
\text { in } 15 \text { European cities }[35,41]\end{array}$ & \multirow{2}{*}{$\begin{array}{l}\text { Temperatures lower than the } 5 \text { th } \\
\text { percentile are strongly associated } \\
\text { with mortality in Cantabria, Spain } \\
\text { [44] }\end{array}$} \\
\hline & \multirow{2}{*}{$\begin{array}{l}\text { Winter excess mortality rate remains a recurring } \\
\text { phenomenon that is quantitatively greater than the } \\
\text { isolated summer event in France [42] }\end{array}$} & \\
\hline & & \multirow{2}{*}{$\begin{array}{l}\text { Extreme cold is associated with } \\
\text { observed } \\
\text { mortality in La Mancha, Spain [45 }\end{array}$} \\
\hline & $\begin{array}{l}\text { Excess winter mortality of } 4597 \text { cases per year for } \\
\text { myocardial infarction in Portugal [43] }\end{array}$ & \\
\hline \multirow{4}{*}{$\begin{array}{l}\text { Observed } \\
\text { morbidity }\end{array}$} & $\begin{array}{l}\text { Low temperature is associated with respiratory tract } \\
\text { infections [46] }\end{array}$ & \\
\hline & $\begin{array}{l}\text { Cold weather had an effect on hospital admission in } 12 \\
\text { cities in Europe [40] }\end{array}$ & \\
\hline & $\begin{array}{l}\text { Significant negative associations between daily average } \\
\text { air temperature and all stroke hospitalizations [39] }\end{array}$ & \\
\hline & $\begin{array}{l}\text { Thermal environment inversely associated with acute } \\
\text { myocardial infarction morbidity during winter [38] }\end{array}$ & \\
\hline \multirow{2}{*}{ Projections } & {$[30] *$} & \\
\hline & {$[19] *$} & \\
\hline
\end{tabular}

Modeling exercises project a mixed pattern of change in fluvial flooding risk across Europe [51]. The British Isles, western and central Europe, regions along the Danube, and northern Italy appear to have a significant increase in future flood hazard, largely due to increases in extreme precipitation events and reduced snow [52]. Approximately 300,000 people are expected to be affected by river flooding per year by the 2050s and up to 390,000 people per year by the 2080s under A1B scenario. People in the United Kingdom, Ireland, Belgium, Luxembourg, France, the Netherlands, Austria, Finland, and Italy will be most affected by river flooding scenarios, despite expected population declines [52,53]. Increases in the number of people affected by river flooding will also occur in Denmark, Germany, Hungary, and Slovakia [52]. Other areas may see a reduction in the number of people affected, particularly northeastern countries including Poland, Estonia, Finland, Latvia, Lithuania, and Sweden; this is likely due to both population decline and a reduction in flood hazard $[28,30,51,54]$.

Sea level rise of about $37 \mathrm{~cm}$ by the 2080s under a A1B scenario (for details on the scenarios, please refer to [55]) is projected to affect 250,000 people per year in Europe directly through coastal flooding if no adaptation occurs [56]. Southern Europe, the northern part of central Europe, Ireland, and the United Kingdom are likely to be most affected. The number of people affected by coastal flooding is higher when using A2 and B2 scenarios; 775,000 to 5.5 million more people may be impacted by 2085 compared to the baseline year 1995 [30].

The health risks of (often storm-related) fluvial and coastal floods are highly varied. Health effects of floods include mortality and morbidity resulting from cardiovascular accidents, drowning and electrocution, traumatic injuries, infectious diseases, and psychological impacts in both the short and long term. Infectious diseases associated with flooding include skin, eye, and respiratory infections, and food-, water-, and vector-borne diseases [57]. Other health effects result from population displacement, damage 
to infrastructure, health service disruption, contamination of drinking water, disruption of food supplies, and the destruction of crops and other agricultural resources [58,59]. Children are at greatest risk of waterborne infectious diseases due to floodwater exposure, with common causative pathogens including Campylobacter jejuni, Giardia, Cryptosporidium, noroviruses, and enteroviruses [60].

Table 4. Search results of literature about health effects from flooding (5).

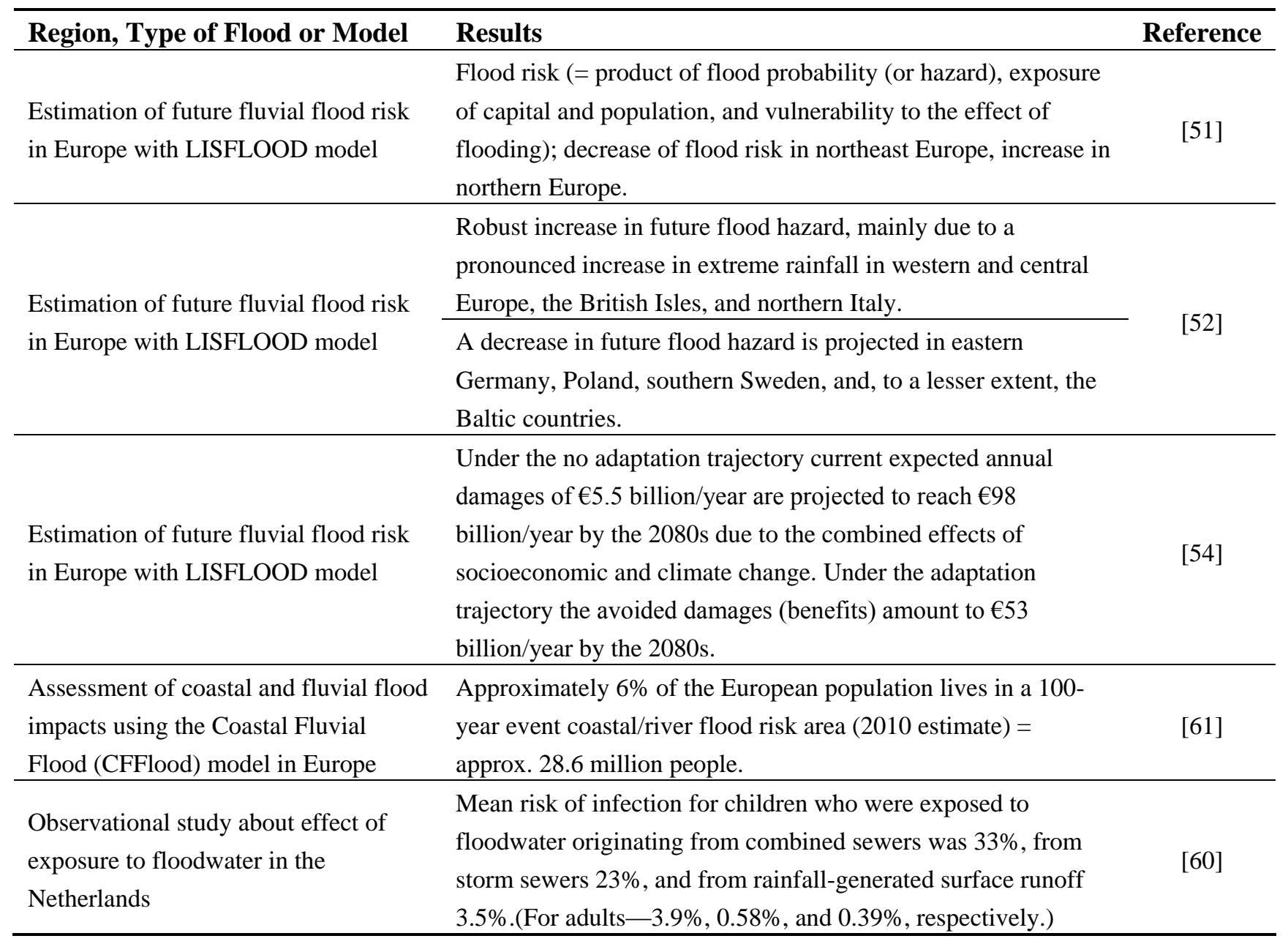

\subsubsection{Wildfires}

Six papers on wildfires were identified in the literature search; they are listed in Table 5. The term wildfire is used to describe the uncontrolled and non-prescribed burning of plants in numerous settings, including forest (forest fires), grassland, and tundra [47]. While most fires in Europe result from human activity, extreme fire events are often assisted by severe weather conditions, and available fuel is a significant determinant of fire behavior [62]. On average, approximately 70,000 fire events occur in Europe each year, affecting more than half a million hectares of forested land. Approximately $70 \%$ of fires occur in the Mediterranean region, with the most damaging fires occurring in the months of July, August, and September [63].

According to the Em-Dat database, 225 people were killed in wildfires in countries belonging to the WHO European Region between 2007 and 2014 [47]. The health effects of wildfires result from direct exposure to fire and smoke, but also indirectly through damage to health facilities, transport infrastructure and communication systems, ecological change, and social disruption [64]. Given their 
highly destructive nature, wildfires and their aftermath may also cause significant psychological distress, both in the short and long term [65].

Fires are also a significant source of air pollutants, including particulate matter [66], volatile organic compounds, and nitrogen and sulfur oxides, products that may be associated with allergic and respiratory diseases. In addition, as more recent studies confirm, these air pollutants promote tropospheric ozone production and radiative forcing, both of which play a role in perpetuating climate change and hence increasing risks to human health [67]. Following forest fires in 2010 near Moscow, the Russian Federation, high levels of $\mathrm{PM}_{10}$ were observed in the city of Moscow, the highest 24-h pollution levels exceeding $300 \mu \mathrm{g} / \mathrm{m}^{3}$ on several days. The fires occurred in the context of a major heat wave that lasted for 44 days, with 24 -h average temperatures ranging from $24{ }^{\circ} \mathrm{C}$ to $31{ }^{\circ} \mathrm{C}$. There were close to 11,000 excess deaths from non-accidental causes including high temperatures and air pollution from wildfires [68].

The risk of wildfires is expected to increase in Europe. Projections show an increase in wildfire risk in many areas, including France, Germany, Belgium, Romania, and Bulgaria, plus southern parts of the Netherlands, Sweden, and Finland. Areas of high and very high wildfire risk will increase by the years 2041-2070. Fire risk is expected to increase most significantly in Greece, Portugal, Spain, and southern Italy $[28,69]$. The projected increase in fire risk is largely due to reductions in summer precipitation [70]. The total burned area in the EU Mediterranean region is expected to increase by $66 \%$ by $2071-2100$ under the B2 scenario, and $140 \%$ under the A2 scenario [69].

Table 5. Search results of literature about health effects from wildfires (6).

\begin{tabular}{|c|c|c|c|}
\hline Geographical Area & Study Type & Result & Reference \\
\hline Greece & $\begin{array}{l}\text { Cross-sectional case control study } \\
\text { following wildfire August } 2007\end{array}$ & $\begin{array}{l}\text { Those exposed to disaster have significantly higher rates } \\
\text { of symptoms including somatization, depression, anxiety, } \\
\text { hostility, phobic anxiety, and paranoia; they are } \\
\text { significantly more distressed than controls. }\end{array}$ & [71] \\
\hline $\begin{array}{l}\text { Peloponnesus } \\
\text { peninsula, Greece }\end{array}$ & Cross-sectional case control study & $\begin{array}{l}400 \text { participants ( } 200 \text { fire-affected, } 200 \text { controls). Fire } \\
\text { victims have a lower quality of life (physical and } \\
\text { psychological health, environment)—but only significant } \\
\text { impairment in quality of life in the environmental domain } \\
\text { after adjustment for confounders. }\end{array}$ & [72] \\
\hline $\begin{array}{l}\text { EU-Mediterranean } \\
\text { countries }\end{array}$ & $\begin{array}{l}\text { Assessment of recorded fires } \\
\text { (1957 to 2007) and projections of } \\
\text { future fire conditions }\end{array}$ & $\begin{array}{l}\text { Under scenarios B2 and A2, seasonal severity rating } \\
\text { (SSR) expected to rise from } 5.3 \text { to } 6.64(+25 \%) \text { and } 7.34 \\
(+38 \%) \text { respectively (SSR = seasonal rating of fire } \\
\text { danger, dependent on fuel moisture and fire behavior } \\
\text { potential, designed to correlate with fire control } \\
\text { difficulty). Iberian Peninsula (Spain, Portugal) and Greece } \\
\text { most affected by increasing fire danger. }\end{array}$ & [69] \\
\hline Portugal & $\begin{array}{l}\text { Assessment of association } \\
\text { between temporal dynamics of } \\
\text { fire events in Portugal and several } \\
\text { variables-socioeconomic, } \\
\text { landscape, climatic }\end{array}$ & $\begin{array}{l}\text { Country-wide increasing trend in numbers of fires from } \\
1980 \text { to mid-1990s, reduction in average area burnt per } \\
\text { individual fire (from approx. } 20 \text { ha in } 1980 \text { s to } 5 \text { ha in } \\
\text { mid-90s). This increase not explained by investigated } \\
\text { climatic factors or temperature/precipitation anomalies; } \\
\text { not significantly correlated with number of forest fires. }\end{array}$ & [73] \\
\hline
\end{tabular}




\begin{tabular}{|c|c|c|c|}
\hline Europe & $\begin{array}{l}\text { Impact assessment and } \\
\text { assessment of adaptation } \\
\text { strategies }\end{array}$ & $\begin{array}{l}\text { In the Mediterranean region the yearly average burned area } \\
\text { is projected to increase by } 150-200 \% \text { by } 2090 \text { (relative to } \\
2000 \text { ). Balkan and eastern European countries will have a } \\
150-560 \% \text { increase in burned areas by } 2090 \text { compared with } \\
2000 \text {. Central EU and Baltic countries: increase in burned } \\
\text { areas of } 120-340 \% \text { by } 2090 \text { (compared with 2000). } \\
\text { Overall, } 65-67 \% \text { reduction in burned area with prescribed } \\
\text { burnings, compared to the "do nothing" scenario. }\end{array}$ & [70] \\
\hline Portugal & $\begin{array}{l}\text { Longitudinal observational } \\
\text { and comparative study }\end{array}$ & $\begin{array}{l}\text { Highest levels of PM fractions were observed during July and } \\
\text { August of } 2010 \text {, corresponding to the periods when majority } \\
(66 \%) \text { of forest fires occurred and significantly higher than } \\
\text { means for the remainder of the year. This may indicate that } \\
\text { forest fires are responsible for increased PM levels. }\end{array}$ & [66] \\
\hline
\end{tabular}

\subsubsection{UV Radiation}

Four papers have been identified that analyze the health effects of UV radiation. Stratospheric ozone depletion is a phenomenon that has been noted as one of the first "symptoms" of global environmental change [74]. The emission of ozone-depleting substances had led to a hole in the ozone layer, above Antarctica. However, consequent implementation of measures agreed to in the Montreal Protocol and the substitution of ozone-depleting substances in many items have successfully stopped the increase in ozone-depleting substances and the stratospheric ozone layer is recovering [75]. Currently, the healthrelevant effects of stratospheric ozone depletion such as skin cancer and cataracts, through changes in UV radiation, are influenced by climate change and changes in cloudiness [76,77] as well as changes in human behavior and exposure related to living at the coast [78] or changing lifestyles [79] (see Table 6, [78-81])).

\subsection{Indirect Health Effects}

\subsubsection{Climate-Sensitive Infectious Diseases}

Temperatures and water availability influence ecosystems and the occurrence of climate-sensitive infectious diseases. Mapping of vulnerabilities to infectious diseases [10] and an assessment of the vulnerability to the risks of infectious disease transmission due to climate change [82] have been undertaken. When researchers studied 2058 outbreaks of 114 infectious diseases occurring in 36 European countries from 1950 to 2009, they found that climatic variations and seasonal changes in the condition of the North Atlantic Oscillation (teleconnection pattern of air pressure leading to warmer/cooler temperatures) influenced the outbreak occurrences of 11 diseases, transmitted through air, water, food, vectors, and rodents [83]. The change in occurrence of infectious diseases in Europe is particularly evident for those transmitted by vectors such as mosquitos, sand flies, and ticks or rodent-borne diseases, and for foodborne diseases as summarized below. Other contributors to changing disease distribution require further assessment, including alterations to vegetation and habitat, human behavior, density and distribution of non-human hosts (such as deer and rodents), and health interventions including vaccination programs [84].

Table 6. Search results about the health effects of UV radiation (4). 


\begin{tabular}{|c|c|c|c|}
\hline Geographical Area & Study Type & Result & Reference \\
\hline Sweden & $\begin{array}{l}\text { Spatial comparison of cancer } \\
\text { incidence and sunshine }\end{array}$ & $\begin{array}{l}\text { Coastal communities (high sun exposure) have higher } \\
\text { incidence of SCC; this correlates with increased UV } \\
\text { radiation exposure. }\end{array}$ & [78] \\
\hline $\begin{array}{l}\text { Europe (southern } \\
\text { Spain, Paris, Berlin, } \\
\text { Stockholm) }\end{array}$ & $\begin{array}{l}\text { Modelling of the UV radiation } \\
\text { relevant for health risks (skin } \\
\text { cancer) and benefits (vitamin D } \\
\text { production) for different scenarios }\end{array}$ & $\begin{array}{l}\text { Estimated reduction of UVR daily doses, but not } \\
\text { sufficient to provide a protection from erythema. On } \\
\text { the other hand, at higher latitudes, UVR reduction } \\
\text { possibly contributes to a relevant increase in the } \\
\text { exposure time necessary for the synthesis of vitamin } \\
\text { D, mainly during the autumn and spring seasons. }\end{array}$ & {$[80]$} \\
\hline Global & Systematic literature review & $\begin{array}{l}\text { UVR exposure is a minor contributor to the world's } \\
\text { disease burden, causing an estimated annual loss of } \\
\text { 1.6 million DALYs; i.e., } 0.1 \% \text { of the total global } \\
\text { disease burden. A markedly larger annual disease } \\
\text { burden, } 3.3 \text { billion DALYs, might result from } \\
\text { reduction in global UVR exposure to very low levels/ }\end{array}$ & [81] \\
\hline Croatia & Observational comparative study & $\begin{array}{l}\text { The incidence of malignant skin melanoma has risen } \\
\text { during the last } 10 \text { years. Different distribution in two } \\
\text { counties could be related to climate changes or } \\
\text { different ways of life. }\end{array}$ & [79] \\
\hline
\end{tabular}

Vector-Borne and Rodent-Borne Diseases

Vector-borne diseases are those transmitted by infected arthropods such as mosquitoes, sand flies, and ticks. These diseases are associated with significant morbidity and mortality across much of the WHO European Region. Arthropod and rodent survival is highly dependent on climate-related factors, with weather affecting habitat, distribution, reproductive capacity, activity, and biting behavior [84]. Several vector-borne diseases in Europe will likely be affected by climate change [85]. The literature search identified 37 relevant papers: 13 about mosquito-borne diseases, 17 papers about tick-borne diseases, five about rodent-borne diseases, and two that dealt generally with climate-sensitive infectious diseases in Europe (see Table 7).

The most relevant climate-sensitive mosquito-borne diseases are malaria, West Nile Fever, Chikungunya, and Dengue. In Europe, most malaria cases are imported and not autochthonous: in 2013 around 5000 imported malaria cases with origin specified were reported, although it is assumed additional cases went unreported [86]. In France and the Netherlands, a few malaria cases without recent travel history were reported [87,88]. The observed and projected risk of malaria was explored for Portugal [89], Turkey [90], Spain [91], and Germany [92]. Although transmission risk may theoretically increase with warming temperatures and provided that suitable mosquito breeding grounds are available, other factors (health system functionality, building and development regulations, and patterns of land use) make the reemergence of malaria in most countries in Europe unlikely [84] (see also Table 7).

Human West Nile fever (WNF) has been described in Europe since 1950. The transmitting vector is the mosquito species Culex, which is widely distributed in Europe. WNF has high rates of asymptomatic infections that make it difficult to monitor [84]. Studies in Israel [93], Hungary, and Austria [94] of neuroinvasive WNF infections indicate that warmer temperatures cause increased mosquito breeding 
activity, which is associated with higher incidence. Increased awareness and increased diagnostic testing have also contributed to the increasing incidence of WNF observed over the last 20 years within 20 countries in the WHO European Region [95].

In 2007, more than 200 cases of Chikungunya (characterized by fever and joint pain, and often causing severe illness in older people with concomitant diseases) were reported in Italy [96]. This viral disease is transmitted by the mosquito Aedes albopictus. Originating in southeast Asia, Aedes albopictus is spreading globally and was reported in Albania in 1979 [97]. The mosquito is now established in southern parts of Europe [98,99] and can transmit not only Chikunguya, but also, among others, Dengue fever [100-103].

The first sustained transmission of Dengue in Europe since the 1920s was reported in 2012 in Madeira, Portugal. A population of the mosquito Aedes aegypti on the island of Madeira led to an outbreak of Dengue fever with 2168 cases, of which 1080 were confirmed. No severe clinical variants or deaths were reported [102,104]. In addition, one autochthonous case was reported in southern France in October 2013 [105]. While Aedes aegypti is re-emerging in Europe, Aedes albopictus is emerging $[106,107]$ and an overall increase in Dengue risk is predicted, with the greatest increase expected in coastal areas of southern Europe [103]; see Table 7.

Table 7. Search results (13) of literature about climate change and mosquito-borne infectious diseases.

\begin{tabular}{|c|c|}
\hline Observed Effect (7) & Observed and Projected Effects (6) \\
\hline Malaria in Portugal [89] & Malaria in Germany [92] \\
\hline Malaria in Turkey [90] & Aedes albopictus in Europe [98] \\
\hline Malaria in Spain [91] & Recent and future Aedes albopictus suitability [99] \\
\hline WNF in Israel [93] & Dengue in Europe [100] \\
\hline WNF in Hungary and Austria [94] & Dengue in Europe [103] \\
\hline $\begin{array}{l}\text { Chikungunya in Italy [96] } \\
\text { Denoue in Madeira 2012 }\end{array}$ & Dengue and Chikungunya in Europe [101] \\
\hline
\end{tabular}

Ticks transmit climate-sensitive infectious diseases including Crimean Congo hemorrhagic fever [108,109], Lyme borreliosis [110-112], tick-borne encephalitis [113-120] and Tularemia [121]. Several studies identified in the literature review do not report on climate change and tick-transmitted diseases, but instead describe changes in tick distribution, specifically in the United Kingdom [122], Slovenia [123], and the Czech Republic [124]. Climate modeling suggests that the geographic range of Ixodes ricinus ticks will increase during the 21 st century. Projections show an increase in the vegetation period and associated tick activity by 2071-2100, with likely increase in tick distribution across Norway, Sweden, and Finland by 2100, resulting in a potential increase in tick-borne diseases [125]. Figure 2 maps the countries with studies on tick-borne diseases retrieved in this search. 


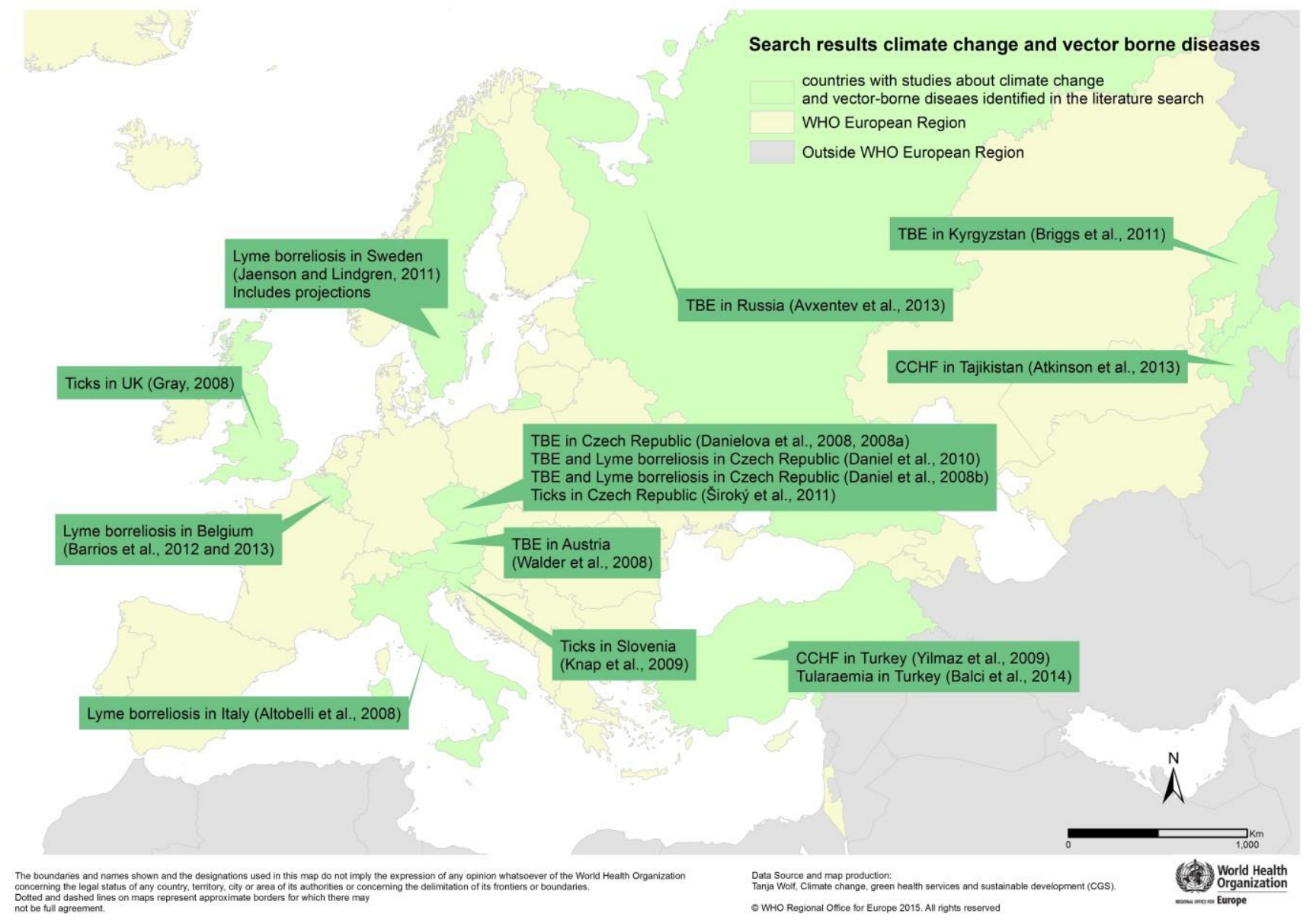

Figure 2. Search results (17) of literature about climate change and tick-borne infectious diseases ([108-111,113-115,117-119,121-128]).

Rodent-borne diseases such as plague, leptospirosis, and hantavirus infections are also sensitive to climatic changes. Rodents can host vectors or act as an intermediate infected host. Plague is endemic in parts of central Asia, particularly Kazakhstan. Rodent populations, and subsequently rates of Yersinia pestis infections, are sensitive to climate factors, owing to effects on food and habitat availability, flea density, and plague transmission [129]. A predicted increase in the aridity of the region may result in an increase in the risk of plague in Europe, particularly in the setting of warmer winters and springs [129,130]. Rodent populations are expected to increase across many parts of Europe and in consequence, rodent-borne diseases are expected to increase [84]. In Europe, leptospirosis occurs mostly in the Mediterranean region and in eastern European countries. Risk factors for human infection include close contact with animals, especially among farmers, abattoir workers, and veterinarians [131]. Heavy precipitation and flooding increase the risk of leptospirosis, a result of increased contact between humans and both Leptospira and their reservoirs related to clean-up after inundation [132]. The number of hantavirus infections has increased significantly in recent years, to over 4000 cases across 24 countries in Europe in 2012 [133]. As for other diseases, it remains unclear whether this increase is a true reflection of disease transmission, or rather the result of improved diagnostic and reporting methods [134]. 


\subsubsection{Food- and Water-Related Diseases}

Climate change can significantly affect basic determinants of good health. Seven papers have been categorized as dealing with health effects related to food and water. This includes communicable diseases and risk related to intoxication from cyanobacteria and mycotoxins (see Table 8).

A study in Kazakhstan confirmed previous knowledge [135] about climate change and the risk of salmonella [136]. In this study an increase in precipitation was associated with an increase in the incidence of salmonellosis, with a lag time of up to two months [136]. Under the SRES A1B climate change scenario, up to 17,000 additional cases of salmonellosis are expected across the European Union by the 2080s, assuming incidence continues at its current level [31]. The incidence of campylobacteriosis in humans is positively associated with mean monthly temperature, with a lag time to disease onset of up to one month [137]. Accordingly, with warming temperatures an increase in the risk of campylobacter infections is also predicted [138].

Flooding and other extreme precipitation events pose a risk to the supply of safe water. Both low and excessive rainfall may be associated with infectious disease outbreaks caused by contaminated drinking water. Droughts are predicted to increase, threatening fresh water supplies, particularly in southern areas of Europe [27]. An increase in extreme precipitation events is expected in Europe as the climate changes [27], with associated increased risks of water-borne diseases such as cryptosporidiosis [138]. Disease outbreaks are also associated with low rainfall in the preceding three weeks [139]. The exceptionally hot summer of 2010 in some parts of Europe may have played a role in an observed increase in Legionnaires' disease [140].

Apart from extreme precipitation, other factors affect food- and water-related diseases; for example, the number of pathogenic Vibrio spp. bacteria is dependent on water salinity and temperature. Vibrio vulnificus infections in Israel correlate with increasing coastal water temperatures [141]. A positive correlation also exists between temperature and cyanobacteria biomass; warmer temperatures produce an increase in the amount of potentially toxic cyanobacteria, with heatwaves therefore increasing the risk of toxic exposure. A corresponding reduction in cyanobacteria biomass occurs during extreme cold events [142].

Table 8. Search results (7) of literature on climate change and diseases related to food and water.

\begin{tabular}{ll}
\hline \multirow{2}{*}{ Related to food } & $\begin{array}{l}\text { Campylobacter in northern Europe [137] } \\
\text { Salmonellosis in Kazakhstan [136] }\end{array}$ \\
\hline & Vibrio in Israel [141] \\
& Rainfall and outbreaks in the United Kingdom [139] \\
Related to water & E. coli in water and mussels in Norway [143] \\
& Toxic cyanobacteria in peri-Alpine lakes [142] \\
& Mycotoxins in maize in the Netherlands [144] \\
\hline
\end{tabular}

\subsubsection{Air Quality}

Air quality is an important health threat in Europe [145]. Evidence shows that air pollution at current levels in European cities is responsible for a significant burden of deaths, hospital admissions and exacerbation of symptoms especially for cardiorespiratory disease. Air contains emissions from motor 
vehicles, industry, heating and commercial sources, as well as tobacco smoke and household fuels. Air pollution harms human health, particularly in those already vulnerable due to age or existing health problems. Exposure to air pollutants is largely beyond individuals' control and requires action by public authorities at the national, regional, and even international levels. Most pollutants are related with those emissions that contribute to climate change. The links between climate change and air pollution are manifold:

(1) Those emissions leading to climate change often also pollute the air. Accordingly the air quality benefits from reducing greenhouse gases.

(2) The impacts of climate change on the atmosphere, temperature, precipitation, and extreme events have a variable effect on the level of air pollution.

(3) Warmer temperatures worsen the health effects of some air pollutants.

The search identified 26 papers, more than was found for other climate change health effects. Not all of them strictly address the links between climate change, air pollution, and health or relate to one of the three mechanisms above. Nonetheless, the findings of the papers are summarized here in the text and in Table 9.

The number of days with ozone concentrations exceeding human health thresholds is expected to increase. This applies particularly to Austria, Belgium, France, Germany, Luxembourg, Italy, and the Netherlands [146]. Regional projections indicate a 10\%-14\% increase in ozone-related morbidity and mortality by 2021-2050 in several countries including Belgium, France, Spain, and Portugal; a decrease in ozone-related morbidity and mortality is predicted in some countries in northern Europe. By 2041-2060 morbidity and mortality are predicted to increase by up to $34 \%$ in some areas [147]. A positive association between high temperatures, ozone, and $\mathrm{PM}_{10}$ concentrations with mortality has been observed, especially on heatwave days $[21,148]$. A $1.66 \%$ mortality increase for each $1{ }^{\circ} \mathrm{C}$ increase in temperature was found on low-ozone days, and $2.1 \%$ on high-ozone days [149]. In a metropolitan area in Portugal, a $10 \mu \mathrm{g} / \mathrm{m}^{3}$ increase in daily eight-hour maximum moving-average ozone is associated with a $0.95 \%$ and $1.58 \%$ increase in non-accidental and cardiovascular mortality, respectively. The effects of ozone are greater among elderly people, and multiple days of increased exposure produce greater effects than only single days $[150,151]$. In addition, it is thought that a proportion of recurrent ischemic cerebrovascular events and myocardial infarction may be triggered by short-term exposure to ozone, the levels of which may increase during heatwaves [152].

Emissions of air pollutants including nitrogen oxides, sulfur dioxide, carbon monoxide, and particulate matter are associated with numerous conditions including respiratory disorders [153], cardiovascular disease, and allergies [154,155]. A significant association is seen between the concentration of $\mathrm{PM}_{10}$ and summer mortality $[151,156]$. A positive relationship has also been found between cardiovascular mortality and concentrations of $\mathrm{PM}_{2.5}$, nitrogen dioxide, and total suspended particulates [157-159].

Children are especially vulnerable to air pollutants. Higher mean annual concentrations of sulfur dioxide, carbon monoxide, nitrogen dioxide, and total suspended particulates have been found to be significantly associated with allergic and respiratory symptoms in children, including rhinitis, rhinoconjunctivits, atopic eczema, and recent severe asthma [160]. Children are particularly vulnerable to changes in air quality, with weekly ozone and sulfur dioxide concentrations associated with the reporting of respiratory symptoms and impaired respiratory function [161]. Exposure of toddlers to ozone and PM10 is associated with an increased likelihood of bronchitis and other respiratory diseases, while intra-uterine 
exposure to carbon monoxide, nitrogen dioxide, sulfur dioxide, and particulate matter have significant negative effects on fetal growth and anthropometric parameters at birth [162,163].

Emissions of numerous pollutants, including sulfur dioxide, nitrogen oxides, and black carbon (an important contributor to particulate matter) have declined in Europe in recent years, owing to both improvements in technology and stricter regulations [164]. This could also lead to a reduction in PM mass concentration [165], although the relation between PM and nitrogen oxides is not fully clear yet. However, other sources of pollutants exist, such as wildfires. A dramatic increase in particulate matter is observed on wildfire days compared with background summer levels $[66,166]$.

Table 9. Search results of literature about climate change, air quality and health (26).

\begin{tabular}{|c|c|c|c|}
\hline Place & Study type & Result & Reference \\
\hline Oporto, Portugal & Observational study & Ozone and PM 10 have adverse effects on health & [151] \\
\hline $\begin{array}{l}\text { Eskisehir, } \\
\text { Turkey }\end{array}$ & $\begin{array}{l}\text { Survey; } \\
\text { cross-sectional study }\end{array}$ & $\begin{array}{l}\text { Elevated ozone levels were associated with upper } \\
\text { respiratory tract complaints in schoolchildren. }\end{array}$ & {$[161]$} \\
\hline $\begin{array}{l}22 \text { cities in the } \\
\text { Mediterranean } \\
\text { and Europe }\end{array}$ & & $\begin{array}{l}\text { Synergistic effects of heat and air pollution } \\
\text { (ozone and } \mathrm{PM}_{10} \text { ) on mortality }\end{array}$ & [148] \\
\hline Dijon, France & Case-crossover study & $\begin{array}{l}\text { Short-term exposure to even low levels of ozone has } \\
\text { an effect on ischemic cerebral and cardiac events. }\end{array}$ & [152] \\
\hline Germany & Descriptive, observational & $\begin{array}{l}\text { Exposure to several air pollutants (ozone, } \mathrm{PM}_{10}, \mathrm{CO} \text {, } \\
\mathrm{NO}_{2}, \mathrm{SO}_{2} \text { ) significantly affects infant and toddler health. }\end{array}$ & [162] \\
\hline Northern Italy & $\begin{array}{l}\text { Descriptive, } \\
\text { observational study }\end{array}$ & $\begin{array}{l}\mathrm{PM}_{2.5}, \text { ozone and } \mathrm{NO}_{2} \text { are estimated to reduce life } \\
\text { expectancy in two towns by } 4 \% \text { (in people aged } \\
30 \text { years) to } 20 \% \text { (in people aged } 85 \text { or more years) }\end{array}$ & [167] \\
\hline Italy (ten cities) & $\begin{array}{l}\text { Time-stratified, } \\
\text { case-crossover analysis }\end{array}$ & $\begin{array}{l}\mathrm{PM}_{10} \text { exposure is associated with respiratory mortality, } \\
\text { especially in summer. More respiratory deaths occur in the cold } \\
\text { season. }\end{array}$ & {$[156]$} \\
\hline $\begin{array}{l}\text { Helsinki, } \\
\text { Finland }\end{array}$ & Observational & $\begin{array}{l}\text { Daily air pollution levels }\left(\mathrm{PM}_{2.5}, \mathrm{NO}_{2} \text { and } \mathrm{CO}\right) \text { is associated } \\
\text { with asthma emergency room visits. There is a } 3-5 \text { day lag } \\
\text { effect in children, but more immediate effect in the adults and } \\
\text { elderly. }\end{array}$ & [168] \\
\hline Czech Republic & $\begin{array}{l}\text { Observational, } \\
\text { cross-sectional study }\end{array}$ & $\begin{array}{l}\text { Association between bronchitis and } \mathrm{NO}_{\mathrm{x}} \text { in children } \\
\text { increases with child's age in the under- } 2 \text { age group }\end{array}$ & {$[160]$} \\
\hline Kotka, Finland & Cohort study & $\begin{array}{l}\text { Even low levels of air pollution }\left(\mathrm{PM}_{2.5}\right) \text { are associated with } \\
\text { higher inflammatory markers in the blood of elderly people. }\end{array}$ & [169] \\
\hline Volos, Greece & Time series study & $\begin{array}{l}\text { Air pollutants have a significant effect on hospitalization } \\
\text { for respiratory and cardiovascular causes. }\end{array}$ & {$[153]$} \\
\hline Israel & Cohort study & $\begin{array}{l}\text { When adjusted for socio-demographic factors, } \\
\text { cumulative chronic exposure to } \mathrm{PM}_{2.5} \text { is positively } \\
\text { associated with reoccurrence of cardiovascular events } \\
\text { in patients after a first myocardial infarction. }\end{array}$ & {$[170]$} \\
\hline Italy & Descriptive, observational & $\begin{array}{l}\mathrm{PM}_{10} \text { has significant impact on COPD hospitalization } \\
\text { for children; ozone has significant influence on } \\
\text { hospitalization of the elderly. }\end{array}$ & {$[150]$} \\
\hline
\end{tabular}

Table 9. Cont. 


\begin{tabular}{|c|c|c|c|}
\hline Place & Study type & Result & Reference \\
\hline Romania & Observational, time series & $\begin{array}{l}\text { Dry air aggravates the adverse effects of total suspended } \\
\text { particles on chronic bronchitis. }\end{array}$ & {$[171]$} \\
\hline Madrid, Spain & $\begin{array}{l}\text { Ecological longitudinal time- } \\
\text { series study }\end{array}$ & $\begin{array}{l}\text { PM is the primary pollutant that showed a statistically } \\
\text { significant association with hospital admission among } \\
\text { people over } 75 \text { years of age. }\end{array}$ & [172] \\
\hline Madrid, Spain & $\begin{array}{l}\text { Longitudinal ecological time- } \\
\text { series }\end{array}$ & $\begin{array}{l}\mathrm{PM}_{2.5} \text { concentrations are an important risk factor for daily } \\
\text { circulatory-cause mortality. }\end{array}$ & {$[157]$} \\
\hline $\begin{array}{l}\text { England, } \\
\text { Belgium, } \\
\text { Germany and } \\
\text { France }\end{array}$ & Simulation/climate modelling & $\begin{array}{l}\text { Simulation of climate change effect on ozone indicates an } \\
\text { increase in ozone concentrations. Higher temperatures are } \\
\text { associated with increased biogenic emissions, less } \\
\text { precipitation, fewer clouds, and increased photolysis. }\end{array}$ & [146] \\
\hline Norway & Cohort study & $\begin{array}{l}\mathrm{NO}_{2}, \mathrm{PM}_{2.5} \text {, and } \mathrm{PM}_{10} \text { have effects on mortality for } \\
\text { cardiovascular causes, lung cancer (threshold effects), and } \\
\text { chronic obstructive pulmonary diseases (linear effects). }\end{array}$ & [173] \\
\hline Vienna, Austria & Time series analysis & $\begin{array}{l}\text { Particulate matter and } \mathrm{NO}_{2} \text { were associated with mortality } \\
\text { from non-trauma causes, even at relatively low levels. }\end{array}$ & {$[158]$} \\
\hline Tuscany, Italy & $\begin{array}{l}\text { Time-stratified case-crossover } \\
\text { approach }\end{array}$ & $\begin{array}{l}\text { Evidence for an association between air pollutants }\left(\mathrm{PM}_{10} \text {, }\right. \\
\left.\mathrm{NO}_{2}, \mathrm{CO}\right) \text { and hospitalization for acute myocardial } \\
\text { infarction was found. }\end{array}$ & [174] \\
\hline Tuscany, Italy & Time series and case-crossover & $\begin{array}{l}\text { Ozone exposure is associated with an increase in out-of- } \\
\text { hospital coronary death but not hospitalized acute } \\
\text { myocardial infarctions. }\end{array}$ & [159] \\
\hline $\begin{array}{l}12 \text { European } \\
\text { countries }\end{array}$ & $\begin{array}{l}\text { Pooled data from } 14 \\
\text { population-based mother-child } \\
\text { cohort studies }\end{array}$ & $\begin{array}{l}\text { Exposure to ambient air pollutants and traffic during } \\
\text { pregnancy is associated with restricted fetal growth } \\
\text { in Europe. }\end{array}$ & [163] \\
\hline $\begin{array}{l}\text { Dresden, } \\
\text { Germany }\end{array}$ & Observational and modelling & $\begin{array}{l}\text { PM mass concentrations are higher in winter and estimated } \\
\text { to decrease in future due to a decrease in sulfate and soot } \\
\text { mass concentrations. }\end{array}$ & [165] \\
\hline $\begin{array}{l}12 \text { countries in } \\
\text { Europe }\end{array}$ & Cohort study & $\begin{array}{l}\text { Long-term exposure to constituents of particles not found } \\
\text { to be statistically significantly associated with total } \\
\text { cardiovascular mortality. }\end{array}$ & [175] \\
\hline $\begin{array}{l}\text { Emilia-Romagna } \\
\text { region, Italy }\end{array}$ & Time series analysis & $\begin{array}{l}\text { In Emilia-Romagna, Italy, there is a positive relationship } \\
\text { between } \mathrm{PM}_{10} \text { and emergency ambulance dispatches (non- } \\
\text { traumatic diseases). }\end{array}$ & [176] \\
\hline Europe & Modelling & $\begin{array}{l}\text { Increase in ground-level ozone and related health impacts } \\
\text { is estimated for Belgium, France, Portugal, and Spain (plus } \\
\text { 10-14\% by 2050), with similar decrease in Nordic and } \\
\text { Baltic countries. By 2041-2060, a strong increase in deaths } \\
\text { and morbidity is expected in Belgium. }\end{array}$ & [147] \\
\hline
\end{tabular}




\subsubsection{Allergic Diseases}

Seventeen eligible papers were identified in this search (see Table 10). It is estimated that between 44 and 76 million people living in the European Union suffer from an allergic disease of the respiratory tract or skin, with up to $90 \%$ of these individuals receiving no or inadequate treatment. Pollens and spores produced by plants are common allergens and trigger allergies. The role of pollen in the development of allergic disease depends on numerous factors, including the duration and intensity of exposure, the annual volume of pollen produced, and the tendency of particular pollen types to trigger allergic responses [177,178]. Climate change is likely to trigger further changes in pollen concentration, volume, and distribution, with an associated increase in the prevalence and severity of allergic diseases in many parts of Europe. While increasing temperatures may prompt earlier flowering and hence prolongation of the pollen season, rising atmospheric carbon dioxide concentrations will result in increased plant growth and pollen production. Furthermore, changing weather patterns may prompt an increase in the geographic range of many allergenic plants, with increasing population risk of allergic disease [177,179,180]. Episodes of acute allergic conditions, including severe asthma, may increase in some areas, owing to an increase in the frequency of thunderstorms known to trigger pollen release [181].

Symptoms of allergic diseases result in absenteeism from work and school and significant productivity loss; it is estimated that allergic diseases generate avoidable costs of $€ 55-151$ billion per year across the European Union [182]. Significant associations have been identified between springtime pollen concentrations and emergency calls for asthma exacerbations among children [183]. Furthermore, an increase in the concentration of Ambrosia pollen by 10 grains $/ \mathrm{m}^{3}$ may increase hospital admissions for respiratory disorders by $25 \%$ [184].

An increase in the annual pollen index (a measure of average daily pollen concentration) has been observed for many taxa of pollen-producing species across Europe [185]. Furthermore, in some areas, pollen and spore concentrations have been found to be positively associated with mean air temperature [186-188]. However, the pattern of change is highly heterogeneous by species, season, and geography [187,189-191]. In northern Italy, an increase in the overall incidence of asthma has been observed [192].

It is important to note that the association between allergic diseases and climate change is not mediated purely by pollen. Increasing air pollution (both as a cause and consequence of climate change), elevated ground-level ozone concentration, and extreme weather events such as thunderstorms and wildfires may all interact with environmental allergens, increasing the frequency and severity of allergic diseases [177]. Links between air pollution and allergic sensitization to common aeroallergens have been assessed, but with mixed results. The European Community Respiratory Health Survey (ECRHS), performed across 29 countries in Europe, found a positive but non-significant association between pollutants, including $\mathrm{PM}_{2.5}$ and sulfur, and sensitization to allergens including pollens [193]. In contrast, a significant increase in asthma symptoms has been observed among pollen-allergic patients, in association with higher concentrations of PM10, sulfur dioxide and ozone [194]. A recent study of Timothy grass (Phleum pratense), commonly found across Europe and a frequent cause of seasonal allergies, found that exposure to elevated concentrations of carbon dioxide increased the amount of pollen produced by each flower by approximately 50\% [195]. Furthermore, studies of Ragweed (Ambrosia artemisiifolia) suggest that both recent and projected increases in atmospheric carbon dioxide concentration may increase the amount of allergenic pollen produced [196,197]. 
Table 10. Search results (17) on climate change and allergic diseases.

\begin{tabular}{|c|c|c|c|}
\hline Place & Study Type & Result & Reference \\
\hline $\begin{array}{l}7 \text { centers in Spain-Asturias, } \\
\text { Barcelona, Bilbao, Cartagena, } \\
\text { La Coruña, Madrid, Valencia }\end{array}$ & $\begin{array}{l}\text { Semi-individual population-based } \\
\text { study based on International } \\
\text { Study of Asthma and Allergies in } \\
\text { Childhood (ISAAC) } \\
\text { cross-sectional study }\end{array}$ & $\begin{array}{l}\text { Higher mean annual concentrations of } \mathrm{SO}_{2} \\
\text { and } \mathrm{CO} \text { are associated with higher prevalence } \\
\text { of symptoms of allergic diseases (rhinitis, } \\
\text { rhino conjunctivitis, eczema, and asthma). }\end{array}$ & [198] \\
\hline 29 countries across Europe & Cross-sectional survey & $\begin{array}{l}\text { No statistically significant associations } \\
\text { between regional air pollution with allergic } \\
\text { sensitization among adults in Europe. }\end{array}$ & [193] \\
\hline Portollano, Spain & Cohort study & $\begin{array}{l}\text { Air pollution levels were associated with an } \\
\text { increased risk of pollen-allergic asthma } \\
\text { symptoms, especially ozone, when exceeding } \\
\text { the health threshold. }\end{array}$ & [194] \\
\hline $\begin{array}{l}\text { Szeged region, Southern } \\
\text { Hungary }\end{array}$ & $\begin{array}{l}\text { Descriptive, observational, } \\
\text { longitudinal }\end{array}$ & $\begin{array}{l}\text { Daily mean concentrations in chemical air } \\
\text { pollutants and Ambrosia and other pollen } \\
\text { have joint effects on allergic asthma } \\
\text { emergency room visits. }\end{array}$ & [199] \\
\hline Szeged, Hungary & Observational, longitudinal study & $\begin{array}{l}\text { In Southern Hungary, Ambrosia, } \mathrm{PM}_{10} \text {, and } \\
\text { ozone are associated with admissions across } \\
\text { all age groups; increased wind speed may } \\
\text { result in admission reduction by } 45 \% \text {. }\end{array}$ & [184] \\
\hline Porto, Portugal & $\begin{array}{l}\text { Observational, cross-sectional } \\
\text { study }\end{array}$ & $\begin{array}{l}\text { Inconsistent correlations between } \mathrm{PM}_{10} \text { and } \\
\text { pollen, and reduced pollen when ozone } \\
\text { increases were observed. }\end{array}$ & [191] \\
\hline $\begin{array}{l}\text { Mainland Portugal—278 } \\
\text { municipalities }\end{array}$ & Retrospective ecological study & $\begin{array}{l}\text { In Portugal, positive associations between } \\
\text { asthma hospital admission rates and } \\
\text { temperature, } \mathrm{NO}_{2} \text {, and } \mathrm{PM}_{10} \text { (summer only); } \\
\text { negative associations with vegetation density. }\end{array}$ & [200] \\
\hline Ankara, Turkey & $\begin{array}{l}\text { Observational cross-sectional } \\
\text { study }\end{array}$ & $\begin{array}{l}\text { A small sample of people suffering from } \\
\text { allergic rhinitis were shown to be sensitive to } \\
\text { mainly tree pollens ( } 95 \%) \text { compared to grasses } \\
(3 \%) \text { and weeds }(2 \%) \text {. }\end{array}$ & [201] \\
\hline Spain & Descriptive, observational & $\begin{array}{l}\text { Presence of Amaranthacaea pollen is } \\
\text { correlated to maximum spring temperature } \\
\text { and rainfall and can change with climate. }\end{array}$ & [188] \\
\hline Cartagena, Spain & Descriptive, observational & $\begin{array}{l}\text { Air pollutants }\left(\mathrm{SO}_{2} \text { and } \mathrm{NO}_{2}\right) \text { and Urticaria } \\
\text { and Poaeceae pollen increase the risk in } \\
\text { asthma hospital emergency room visits; } \mathrm{NO}_{2} \\
\text { and } \mathrm{SO}_{2} \text { also increase the risk in ER visits } \\
\text { due to chronic obstructive pulmonary disease. }\end{array}$ & [202] \\
\hline Thessaloniki, Greece & $\begin{array}{l}\text { Descriptive, observational, time } \\
\text { series }\end{array}$ & $\begin{array}{l}\text { Pollen levels, mainly of woody plants, are } \\
\text { almost doubling each decade in Thessaloniki, } \\
\text { Greece and this coincides with a rise in air } \\
\text { temperature. }\end{array}$ & [190] \\
\hline
\end{tabular}


Table 10. Cont.

\begin{tabular}{|c|c|c|c|}
\hline Place & Study Type & Result & Reference \\
\hline Hungary & Observational & $\begin{array}{l}\text { Total annual pollen counts have increased. The changes } \\
\text { in pollen season characteristics were in accordance with } \\
\text { risk and expansion potential due to climate change. }\end{array}$ & [189] \\
\hline Poland & Observational, comparative & $\begin{array}{l}\text { The spore count of two species of fungal spores is } \\
\text { mainly determined by air temperature. }\end{array}$ & [186] \\
\hline Hungary & Descriptive, observational & $\begin{array}{l}\text { Pollen amount increases with mean temperature and } \\
\text { rainfall; little change in duration of pollination season. }\end{array}$ & [187] \\
\hline $\begin{array}{l}\text { Parma area (northern } \\
\text { Italy) }\end{array}$ & Longitudinal descriptive study & $\begin{array}{l}\text { In Parma, Italy, a significant increase in the incidence } \\
\text { of allergy (to mites, pets, and birch family pollens) and } \\
\text { asthma was observed, while allergic reactions to } \\
\text { grasses and rhino conjunctivitis decreased and were } \\
\text { correlated to a decrease in pollen count, pollen } \\
\text { concentration peaks, and pollination period. }\end{array}$ & [192] \\
\hline Genoa, Italy & Descriptive observational study & $\begin{array}{l}\text { In Genoa, Italy, asthma exacerbations have seasonal } \\
\text { peaks in spring and autumn and are associated with } \\
\text { pollen concentration, wind speed, and rainfall as well } \\
\text { as chemical pollutants }\left(\mathrm{SO}_{2}, \mathrm{NO} \text {, and } \mathrm{NO}_{2}\right) \text {. }\end{array}$ & [203] \\
\hline $\begin{array}{l}13 \text { countries across } \\
\text { Europe }\end{array}$ & Time series analysis & Increases in airborne pollen for many taxa in Europe. & [185] \\
\hline
\end{tabular}

\section{Discussion}

This literature review for 2007 to 2014 has identified a large amount of research in the area of climate change and health. The large number of papers identified in the initial search was reduced to 135 original research papers that contribute to evidence following the known attribution pathways of climate change. In addition to the observed evidence, studies project that:

- Heat-related mortality is likely to increase, particularly in southern parts of Europe, owing to an increase in the frequency and severity of heatwaves.

- The threat of extreme weather events will grow, with river floods and coastal flooding and associated health effects.

- Wildfire risk is likely to intensify significantly in countries such as Greece, Spain, Portugal, and Italy, with associated threats to life, agriculture, and property.

- The distribution of tick-borne diseases may grow as temperatures increase, and conditions may favor the reintroduction of mosquito-borne diseases including Dengue fever and malaria into parts of Europe.

- Morbidity and mortality caused by air pollution, particularly rising levels of ground-level ozone, may increase, as may allergic diseases due to changes in pollen and aeroallergen production, distribution, and allergenicity.

- The interaction of climate change and changing weather conditions with stratospheric ozone concentration, their joint impacts on UV radiation and human exposure to it is under exploration. The health effects (on the skin, eyes, immunity, etc.) are also determined by lifestyle and behavior. 
There are some limitations to this review. Firstly, the search is limited to the already known attribution pathways of climate change. There may be further unknown associations between climate and health and it is difficult to draw the line for inclusion. Further, the increasing number of papers on climate change and health makes it extremely difficult to maintain an adequate overview of emerging evidence. It was very difficult to create a search algorithm that would fit the research question, and a very laborintensive manual selection process was required. This made the paper outdated by the time it was ready for submission. In addition, it is very difficult to decide how much evidence is required to determine the attribution of health effects to climate change. In this review, and in particular in the areas of air quality and allergies, a rather broad definition of issues and papers that may be relevant to known pathways of climate change and health has been applied. Accordingly, the number of papers identified was relatively high. For other sections, for example regarding the health effects of flooding and changes in food and water, the number of studies identified was fewer.

\section{Conclusions}

This literature review shows that evidence about the direct and indirect health effects of climate change and future health risks for the WHO European Region is emerging. Acknowledging the multitude of contributors to human health, the literature is increasingly reflective of multidisciplinary approaches and comprehensive, integrated assessments of environment and health. However, the science clearly demonstrates that significant changes are occurring; robust policy is now required to push for effective mitigation and adaptation actions in all sectors. Climate change threatens human health, but may be considered a challenge and a strong argument for a transition to more sustainable and healthy societies with "climate-resilient" health systems.

\section{Acknowledgments}

Thanks to Marina Ostheimer and Yorck Adrian, who contributed to an earlier literature search, and to Kristen Scott, who helped prepare the summary tables. Thanks also to Bettina Menne for advice throughout the development of the manuscript. The work was done in the context of the IMPACT2C research project with funding from the European Union Seventh Framework Program (FP7/2007-2013) under grant agreement 282746.

\section{Author Contributions}

Tanja Wolf planned the literature search, with the support of Marina Ostheimer and Yorck Adrian. Gerardo Sanchez took over and re-did the literature search with Katrina Lyne, who wrote summaries of the selected papers. Tanja Wolf drafted the manuscript and Vladimir and Gerardo helped shorten it substantially.

\section{Conflicts of Interest}

The authors declare no conflict of interest. 


\section{References}

1. IPCC. IPCC summary for policymakers. In Climate Change 2014: Impacts, Adaptation, and Vulnerability. Part A: Global and Sectoral Aspects. Contribution of Working Group II to the Fifth Assessment Report of the Intergovernmental Panel on Climate Change; Field, C.B., Barros, V.R., Dokken, D.J., Mach, K.J., Mastrandrea, M.D., Bilir, T.E., Chatterjee, M., Ebi, K.L., Estrada, Y.O., Genova, R.C., et al., Eds.; Cambridge University Press: Cambridge, UK; New York, NY, USA, 2014; pp. 1-32.

2. Kovats, R.S.; Valentini, R.; Bouwer, L.; Georgopoulou, E.; Jacob, D.; Martin, E.; Rounsevell, M.; Soussana, J.F. Part B: Regional aspects. In Climate Change 2014: Impacts, Adaptation, and Vulnerability; Barros, V., Field, C., Dokken, D., Mastrandrea, M., Mach, K., Bilir, T., Chatterjee, M., Ebi, K., Estrada, Y., Genova, R., et al., Eds.; Cambridge University Press: Cambridge, UK; New York, NY, USA, 2014; pp. 1267-1326.

3. Smith, K.; Woodward, A.; Campbell-Lendrum, D.; Chadee, D.; Honda, Y.; Liu, Q.; Olwoch, J.; Revich, B.; Sauerborn, R. Human health: Impacts, adaptation, and co-benefits. In Climate Change 2014: Impacts, Adaptation, and Vulnerability. Part A: Global and Sectoral Aspects; Cambridge University Press: Cambridge, UK; New York, NY, USA, 2014; pp. 709-754.

4. World Health Organization. Protecting Health in Europe from Climate Change; Menne, B., Apfel, F., Kovats, S., Racioppi, F., Eds.; World Health Organization Regional Office for Europe: Copenhagen, Denmark, 2008.

5. WHO. Quantitative Risk Assessment of the Effects of Climate Change on Selected Causes of Death, 2030 s and 2050s; Hales, S., Kovats, S., Lloyd, S., Campbell-Lendrum, D., Eds.; World Health Organization (WHO): Geneva, Switzerland, 2014; p. 128.

6. Costello, A.; Abbas, M.; Allen, A.; Ball, S.; Bell, S.; Bellamy, R.; Friel, S.; Groce, N.; Johnson, A.; Kett, M.; et al. Managing the health effects of climate change: Lancet and University College London Institute for Global Health Commission. Lancet 2009, 373, 1693.

7. Watts, N.; Adger, W.N.; Agnolucci, P.; Blackstock, J.; Byass, P.; Cai, W.; Chaytor, S.; Colbourn, T.; Collins, M.; Cooper, A.; et al. Health and climate change: Policy responses to protect public health. Lancet 2015, 386, e28-e31.

8. Chan, M. Achieving a cleaner, more sustainable, and healthier future. Lancet (Lond. Engl.) 2015, 386, e27-e28.

9. Wolf, T.; Martinez, G.S.; Cheong, H.-K.; Williams, E.; Menne, B. Protecting health from climate change in the WHO European region. Int. J. Environ. Res. Public Health 2014, 11, 6265-6280.

10. Semenza, J.C.; Suk, J.E.; Estevez, V.; Ebi, K.L.; Lindgren, E. Mapping climate change vulnerabilities to infectious diseases in Europe. Environ. Health Perspect. 2012, 120, 385-392.

11. Liberati, A.; Altman, D.G.; Tetzlaff, J.; Mulrow, C.; Gøtzsche, P.C.; Ioannidis, J.P.A; Clarke, M.; Devereaux, P.J.; Kleijnen, J.; Moher, D. The PRISMA Statement for Reporting Systematic Reviews and Meta-Analyses of Studies that Evaluate Health Care Interventions: Explanation and Elaboration. BMJ. 2009, 339, b2700.

12. European Commission. CORDIS Community Research and Development Information Service. Avaliable online: http://cordis.europa.eu/ (accessed on 10 November 2015). 
13. Robine, J.M.; Cheung, S.L. K.; le Roy, S.; van Oyen, H.; Griffiths, C.; Michel, J.P.; Herrmann, F.R. Death toll exceeded 70,000 in Europe during the summer of 2003. C.R. Biol. 2008, 331, 171-178.

14. Amengual, A.; Homar, V.; Romero, R.; Brooks, H.E.; Ramis, C.; Gordaliza, M.; Alonso, S. Projections of heat waves with high impact on human health in Europe. Glob. Planet. Chang. 2014, 119, 71-84.

15. D’Ippoliti, D.; Michelozzi, P.; Marino, C.; de'Donato, F.; Menne, B.; Katsouyanni, K.; Kirchmayer, U.; Analitis, A.; Medina-Ramón, M.; Paldy, A.; et al. The impact of heat waves on mortality in 9 European cities: Results from the EuroHEAT project. Environ. Health 2010, doi:10.1186/1476-069X-9-37.

16. Montero, J.C.; Mirón, I.J.; Criado-Álvarez, J.J.; Linares, C.; Díaz, J. Influence of local factors in the relationship between mortality and heat waves: Castile-La Mancha (1975-2003). Sci. Total Environ. 2012, 414, 73-80.

17. Gabriel, K.M.A.; Endlicher, W.R. Urban and rural mortality rates during heat waves in Berlin and Brandenburg, Germany. Environ. Pollut. 2011, 159, 2044-2050.

18. Leone, M.; D’Ippoliti, D.; de Sario, M.; Analitis, A.; Menne, B.; Katsouyanni, K.; de' Donato, F.K.; Basagana, X.; Salah, A.B.; Casimiro, E.; et al. A time series study on the effects of heat on mortality and evaluation of heterogeneity into European and Eastern-Southern Mediterranean cities: Results of EU CIRCE project. Environ. Health Glob. Access. Sci. Source 2013, 12, 55.

19. Morabito, M.; Crisci, A.; Moriondo, M.; Profili, F.; Francesconi, P.; Trombi, G.; Bindi, M.; Gensini, G.F.; Orlandini, S. Air temperature-related human health outcomes: Current impact and estimations of future risks in Central Italy. Sci. Total Environ. 2012, 441, $28-40$.

20. Theoharatos, G.; Pantavou, K.; Mavrakis, A.; Spanou, A.; Katavoutas, G.; Efstathiou, P.; Mpekas, P.; Asimakopoulos, D. Heat waves observed in 2007 in Athens, Greece: Synoptic conditions, bioclimatological assessment, air quality levels and health effects. Environ. Res. 2010, 110, $152-161$.

21. Burkart, K.; Canário, P.; Breitner, S.; Schneider, A.; Scherber, K.; Andrade, H.; Alcoforado, M.J.; Endlicher, W. Interactive short-term effects of equivalent temperature and air pollution on human mortality in Berlin and Lisbon. Environ. Pollut. 2013, 183, 54-63.

22. Conti, S.; Masocco, M.; Meli, P.; Minelli, G.; Palummeri, E.; Solimini, R.; Toccaceli, V.; Vichi, M. General and specific mortality among the elderly during the 2003 heat wave in Genoa (Italy). Environ. Res. 2007, 103, 267-274.

23. Josseran, L.; Caillere, N.; Brun-Ney, D.; Rottner, J.; Filleul, L.; Brucker, G.; Astagneau, P.; Caillère, N.; Brun-Ney, D.; Rottner, J.; et al. Syndromic surveillance and heat wave morbidity: A pilot study based on emergency departments in France. BMC Med. Inform. Decis. Mak. 2009, 9, 14.

24. Michelozzi, P.; Accetta, G.; de Sario, M.; d'Ippoliti, D.; Marino, C.; Baccini, M.; Biggeri, A.; Anderson, H.R.; Katsouyanni, K.; Ballester, F.; et al. On behalf of the PHEWE collaborative group high temperature and hospitalizations for cardiovascular and respiratory causes in 12 European cities. Am. J. Respir. Crit. Care Med. 2009, 179, 383-389.

25. Alessandrini, E.; Zauli Sajani, S.; Scotto, F.; Miglio, R.; Marchesi, S.; Lauriola, P. Emergency ambulance dispatches and apparent temperature: A time series analysis in Emilia-Romagna, Italy. Environ. Res. 2011, 111, 1192-1200. 
26. Vicedo-Cabrera, A.M.; Iñíguez, C.; Barona, C.; Ballester, F. Exposure to elevated temperatures and risk of preterm birth in Valencia, Spain. Environ. Res. 2014, 134, 210-217.

27. Watkiss, P.; Gobiet, A.; Jacob, D.; Kjellstrom, E.; Kotova, L.; Landgren, O.; Lenderink, G.; Mendlik, T.; Nikulin, G.; Sobolowski, S.; Teichmann, C.; Vautard, R. IMPACT2C Policy Update on $2{ }^{\circ} \mathrm{C}$ Warming; Climate Service Center: Hamburg, Germany, 2013.

28. Lung, T.; Lavalle, C.; Hiederer, R.; Dosio, A.; Bouwer, L.M. A multi-hazard regional level impact assessment for Europe combining indicators of climatic and non-climatic change. Glob. Environ. Chang. 2013, 23, 522-536.

29. Åström, C.; Orru, H.; Rocklöv, J.; Strandberg, G.; Ebi, K.L.; Forsberg, B. Heat-related respiratory hospital admissions in Europe in a changing climate: A health impact assessment. BMJ Open 2013, 3, e001842.

30. Ciscar, J.C.C.; Iglesias, A.; Feyen, L.; Goodess, C.M.; Szabo, L.; Christensen, O.B.; Nicholls, R.; Amelung, B.; Watkiss, P.; Bosello, F.; et al. Climate Change Impacts in Europe; Final Report of the PESETA Research Project; European Commission Joint Research Centre: Seville, Spain, 2009.

31. Kovats, S.; Lloyd, S.; Hunt, A.; Watkiss, P. Technical policy briefing Note 5: The impacts and economic costs on health in Europe, and the costs and benefits of adaptation, results of the EC RTD ClimateCost Project. In The ClimateCost Project. Final Report. Volume 1: Europe; Watkiss, P., Ed.; Stockholm Environment Institute: Stockholm, Sweden, 2011; pp. 1-31.

32. Schifano, P.; Leone, M.; de Sario, M.; de'Donato, F.; Bargagli, A.M.; d'Ippoliti, D.; Marino, C.; Michelozzi, P. Changes in the effects of heat on mortality among the elderly from 1998-2010: Results from a multicenter time series study in Italy. Environ. Health Glob. Access. Sci. Source 2012, 11, 58 .

33. Kriszbacher, I.; Bódis, J.; Csoboth, I.; Boncz, I. The occurrence of acute myocardial infarction in relation to weather conditions. Int. J. Cardiol. 2009, 135, 136-138.

34. Robine, J.M.M.; Michel, J.P.P.; Herrmann, F.R.R. Excess male mortality and age-specific mortality trajectories under different mortality conditions: A lesson from the heat wave of summer 2003. Mech. Ageing Dev. 2012, 133, 378-386.

35. Analitis, A.; Katsouyanni, K.; Biggeri, A.; Baccini, M.; Forsberg, B.; Bisanti, L.; Kirchmayer, U.; Ballester, F.; Cadum, E.; Goodman, P.G.; et al. Effects of cold weather on mortality: Results from 15 European cities within the PHEWE project. Am. J. Epidemiol. 2008, 168, 1397-1408.

36. Hajat, S.; Kovats, R.S. S.; Lachowycz, K. Heat-related and cold-related deaths in England and Wales: Who is at risk? Occup. Env. Med. 2007, 64, 93-100.

37. Falagas, M.E.; Bliziotis, I.A.; Kosmidis, J.; Daikos, G.K. Unusual climatic conditions and infectious diseases: Observations made by Hippocrates. Enferm. Infect. Microbiol. Clin. 2010, $28,716-718$.

38. Vasconcelos, J.; Freire, E.; Almendra, R.; Silva, G.L.; Santana, P. The impact of winter cold weather on acute myocardial infarctions in Portugal. Environ. Pollut. 2013, 183, 14-18.

39. Morabito, M.; Crisci, A.; Vallorani, R.; Modesti, P.A.; Gensini, G.F.; Orlandini, S. Innovative approaches helpful to enhance knowledge on weather-related stroke events over a wide geographical area and a large population. Stroke 2011, 42, 593-600. 
40. Marino, C.; de'Donato, F.; Michelozzi, P.; d'Ippoliti, D.; Katsouyanni, K.; Analitis, A.; Biggeri, A.; Baccini, M.; Accetta, G.; Perucci, C. A Effects of cold weather on hospital admissions: Results from 12 European cities within the PHEWE project. Epidemiology 2009, 20, S67-S68.

41. Gómez-Acebo, I.; Llorca, J.; Dierssen, T. Cold-related mortality due to cardiovascular diseases, respiratory diseases and cancer: A case-crossover study. Public Health 2013, 127, 252-258.

42. Phu Pin, S.; Golmard, J.L.; Cotto, E.; Rothan-Tondeur, M.; Chami, K.; Piette, F. Excess winter mortality in France: Influence of temperature, influenza like illness, and residential care status. J. Am. Med. Dir. Assoc. 2012, 13, e309.

43. Vasconcelos, J.; Freire, E.; Morais, J.; Machado, J.R.; Santana, P. The health impacts of poor housing conditions and thermal discomfort. Procedia Environ. Sci. 2011, 4, 158-164.

44. Gómez-Acebo, I.; Dierssen-Sotos, T.; Llorca, J. Effect of cold temperatures on mortality in Cantabria (Northern Spain): A case-crossover study. Public Health 2010, 124, 398-403.

45. Montero, J.C.; Mirón, I.J.; Criado-Álvarez, J.J.; Linares, C.; Díaz, J. Mortality from cold waves in Castile-La Mancha, Spain. Sci. Total Environ. 2010, 408, 5768-5774.

46. Falagas, M.E.; Theocharis, G.; Spanos, A.; Vlara, L.A.; Issaris, E.A.; Panos, G.; Peppas, G. Effect of meteorological variables on the incidence of respiratory tract infections. Respir. Med. 2008, 102, 733-737.

47. Guha-Sapir, D.; Below, R.; Hoyois, P. EM-DAT The International Disaster Datablase, Centre for Research in Epidemiology of Disasters - CRED. Available online: http://www.emdat.be (accessed on 6 October 2011).

48. EEA. Climate Change, Impacts and Vulnerability in Europe 2012: An Indicator-Based Report; Rosendahls-Schultz Grafisk: Copenhagen, Denmark, 2012.

49. Bindi, M.; Olesen, J.E. The responses of agriculture in Europe to climate change. Reg. Environ. Chang. 2010, 11, 151-158.

50. Borga, M.; Anagnostou, E.; Blöschl, G.; Creutin, J.D. Flash flood forecasting, warning and risk management: The HYDRATE project. Environ. Sci. Policy 2011, 14, 834-844.

51. Feyen, L.; Dankers, R.; Bódis, K.; Salamon, P.; Barredo, J.I. Fluvial flood risk in Europe in present and future climates. Clim. Chang. 2011, 112, 47-62.

52. Rojas, R.; Feyen, L.; Bianchi, A.; Dosio, A. Assessment of future flood hazard in Europe using a large ensemble of bias corrected regional climate simulations. J. Geophys. Res. 2012, 117, D17109.

53. Ciscar, J.C.; Feyen, L.; Soria, A.; Lavalle, C.; Raes, F.; Perry, M.; Nemry, F.; Demirel, H.; Rozsai, M.; Dosio, A.; et al. Climate Impacts in Europe: The JRC PESETA II Project; European Commission Joint Research Centre: Seville, Spain, 2014.

54. Rojas, R.; Feyen, L.; Watkiss, P. Climate change and river floods in the European Union: Socio-economic consequences and the costs and benefits of adaptation. Glob. Environ. Chang. 2013, 23, 1737-1751.

55. Nakicenovic, N.; Alcamo, J.; Davis, G.; de Vries, B.; Fenhann, J.; Gaffin, S.; Gregory, K.; Grübler, A.; Jung, T.Y.; Kram, T.; et al. IPCC Special Report: Emissions Scenarios. Summary for Policymakers. Summary for Policymakers Emissions Scenarios A Special Report of IPCC Working Group III; Nakicenovic, N., Swart, R., Eds.; Cambridge University Press: Cambridge, UK, 2000. 
56. Brown, S.; Nicholls, R.J.R.; Vafeidis, A.; Hinkel, J.; Watkiss, P.; Watkiss, P. The Impacts and Economic Costs of Sea-Level Rise in Europe and the Costs and Benefits of Adaptation. Summary of Results from the EC RTD ClimateCost Project; Technical Policy Briefing Note 2; Stockholm Environment Institute: Stockholm, Sweden, 2011.

57. Jakubicka, T.; Vos, F.; Phalkey, R.; Marx, M.; Guha-Sapir, D. Health Impacts of Floods in Europe. Data Gaps and Information Needs from a Spatial Perspective; MICRODIS: Heidelberg, Germany, 2010.

58. Vasconcelos, P. Flooding in Europe: A brief review of the health risks. Eurosurveillance 2006, 11, 2947.

59. WHO. Floods in the WHO European Region: Health Effects and Their Prevention; WHO: Copenhagen, Denmark, 2013.

60. De Man, H.; van den Berg, H.H.J.L.; Leenen, E.J.T.M.; Schijven, J.F.; Schets, F.M.; van der Vliet, J.C.; van Knapen, F.; de Roda Husman, A.M. Quantitative assessment of infection risk from exposure to waterborne pathogens in urban floodwater. Water Res. 2014, 48, 90-99.

61. Mokrech, M.; Kebede, A.; Nicholls, R.; Wimmer, F. An integrated approach for assessing flood impacts due to future climate and socio-economic conditions and the scope of adaptation in Europe. In Climatic Change: Regional Integrated Assessment of Cross-Sectoral Climate Change Impacts, Adaptation, and Vulnerability; Harrison, P., Berry, P., Eds.; Springer: Dordrecht, The Netherlands 2014; pp. 245-260.

62. EEA Indicator Assessment: CLIM 035: Forest Fires. Available online: http://www.eea.europa.eu/ data-and-maps/indicators/forest-fire-danger-1/assessment (accessed on 18 January 2015).

63. EEA. Mapping the Impacts of Natural Hazards and Technological Accidents in Europe: An Overview of the Last Decade; European Environment Agency: Copenhagen, Denmark, 2010.

64. Finlay, S.; Moffat, A.; Gazzard, R.; Baker, D.; Murray, V. Health impacts of wildfires. PLoS Curr. Disasters 2012, 1, doi:10.1371/4f959951cce2c.

65. Adamis, D.; Papanikolaou, V.; Mellon, R.C.; Prodromitis, G.; Tyrovola, K.; Kyriopoulos, J. Long-term psychological effects of a wildfire disaster in Greece. Eur. Psychiatry 2012, 27, 1.

66. Slezakova, K.; Morais, S.; Pereira, M.C. Forest fires in Northern region of Portugal: Impact on PM levels. Atmos. Res. 2013, 127, 148-153.

67. Youssouf, H.; Liousse, C.; Roblou, L.; Assamoi, E.M.; Salonen, R.O.; Maesano, C. Quantifying wildfires exposure for investigating health-related effects. Atmos. Environ. 2014, 97, 239-251.

68. Shaposhnikov, D.; Revich, B.; Bellander, T.; Bedada, G.B.; Bottai, M.; Kharkova, T.; Kvasha, E.; Lezina, E.; Lind, T.; Semutnikova, E.; et al. Mortality related to air pollution with the Moscow heat wave and wildfire of 2010. Epidemiology 2014, 25, 359-364.

69. Amatulli, G.; Camia, A.; San-Miguel-Ayanz, J. Estimating future burned areas under changing climate in the EU-Mediterranean countries. Sci. Total Environ. 2013, 450-451, 209-222.

70. Khabarov, N.; Krasovskii, A.; Obersteiner, M.; Swart, R.; Dosio, A.; San-Miguel-Ayanz, J.; Durrant, T.; Camia, A.; Migliavacca, M. Forest fires and adaptation options in Europe. Reg. Environ. Chang. 2014, doi:10.1007/s10113-014-0621-0.

71. Adamis, D.; Papanikolaou, V.; Mellon, R.C.; Prodromitis, G. The impact of wildfires on mental health of residents in a rural area of Greece. A case control population based study. Eur. Psychiatry 2011, 26, 1188. 
72. Papanikolaou, V.; Adamis, D.; Kyriopoulos, J. Long term quality of life after a wildfire disaster in a rural part of Greece. Open J. Psychiatry 2012, 2, 164-170.

73. Costa, L.; Thonicke, K.; Poulter, B.; Badeck, F.W. Sensitivity of Portuguese forest fires to climatic, human, and landscape variables: Subnational differences between fire drivers in extreme fire years and decadal averages. Reg. Environ. Chang. 2010, 11, 543-551.

74. Rockström, J.; Steffen, W.; Noone, K.; Persson, Å.; Chapin, F.S.; Lambin, E.F.; Lenton, T.M.; Scheffer, M.; Folke, C.; Schellnhuber, H.J.; et al. A safe operating space for humanity. Nature 2009, 461, 472-475.

75. Bais, A.F.; McKenzie, R.L.; Bernhard, G.; Aucamp, P.J.; Ilyas, M.; Madronich, S.; Tourpali, K.; Bais, A.F.; Björn, L.O.; Ilyas, M.; et al. Ozone depletion and climate change: Impacts on UV radiation. Photochem. Photobiol. Sci. 2014, 14, 19-52.

76. Norval, M.; Lucas, R.M.; Cullen, A.P.; de Gruijl, F.R.; Longstreth, J.; Takizawa, Y.; van der Leun, J.C. The human health effects of ozone depletion and interactions with climate change. Photochem. Photobiol. Sci. Off. J. Eur. Photochem. Assoc. Eur. Soc. Photobiol. 2011, 10, 199-225.

77. Lucas, R.M.; Norval, M.; Neale, R.E.; Young, A.R.; de Gruijl, F.R.; Takizawa, Y.; van der Leun, J.C. The Consequences for Human Health of Stratospheric Ozone Depletion in Association with Other Environmental Factors-c4pp90033b. Available online: http://pubs.rsc. org/en/content/articlepdf/2015/pp/c4pp90033b (accessed on 15 January 2015).

78. Andersson, E.M.; Paoli, J.; Wastensson, G. Incidence of cutaneous squamous cell carcinoma in coastal and inland areas of Western Sweden. Cancer Epidemiol. 2011, 35, e69-e74.

79. Materljan, E.; Zamolo, G.; Petkovic, M.; Ivosevic, D.; Popovic, B.; Materljan, M.; Katunaric, M.; Jurisic, D. Malignant skin melanoma in Croatia. Coll. Antropol. 2009, 33, 1363-1368.

80. Corrêa, M.D.P.; Godin-Beekmann, S.; Haeffelin, M.; Bekki, S.; Saiag, P.; Badosa, J.; Jégou, F.; Pazmiño, A.; Mahé, E. Projected changes in clear-sky erythemal and vitamin D effective UV doses for Europe over the period 2006 to 2100. Photochem. Photobiol. Sci. 2013, 12, 1053-1064.

81. Lucas, R.M.; McMichael, A.J.; Armstrong, B.K.; Smith, W.T. Estimating the global disease burden due to ultraviolet radiation exposure. Int. J. Epidemiol. 2008, 37, 654-667.

82. Suk, J.E.; Ebi, K.L.; Vose, D.; Wint, W.; Alexander, N.; Mintiens, K.; Semenza, J.C. Indicators for tracking European vulnerabilities to the risks of infectious disease transmission due to climate change. Int. J. Environ. Res. Public Health 2014, 11, 2218-2235.

83. Morand, S.; Owers, K.A.; Waret-Szkuta, A.; McIntyre, K.M.; Baylis, M. Climate variability and outbreaks of infectious diseases in Europe. Sci. Rep. 2013, 3, 1774.

84. Semenza, J.C.; Menne, B. Climate change and infectious diseases in Europe. Lancet Infect. Dis. 2009, 9, 365-375.

85. Lindgren, E.; Andersson, Y.; Suk, J.E.; Sudre, B.; Semenza, J.C. Monitoring EU emerging infectious disease risk due to climate change. Science 2012, 336, 418-419.

86. WHO. Regional Office for Europe Information leaflet: Malaria in the WHO European Region (English); WHO: Geneva, Switzerland, 2015. 
87. Arends, J.E.; Oosterheert, J.J.; Kraaij-Dirkzwager, M.M.; Kaan, J.A.; Fanoy, E.B.; Haas, P.J.; Scholte, E.J.; Kortbeek, L.M.; Sankatsing, S.U.C. Two cases of Plasmodium falciparum malaria in the Netherlands without recent travel to a malaria-endemic country. Am. J. Trop. Med. Hyg. 2013, 89, 527-530.

88. Gallien, S.; Taieb, F.; Hamane, S.; De Castro, N.; Molina, J.M. Autochthonous falciparum malaria possibly transmitted by luggage-carried vector in Paris, France, February 2013. Eurosurveillance 2013, 18, doi:10.2807/1560-7917.ES2013.18.40.20600.

89. Benali, A.; Nunes, J.P.; Freitas, F.B.; Sousa, C.A.; Novo, M.T.; Lourenço, P.M.; Lima, J.C.; Seixas, J.; Almeida, A.P.G. Satellite-derived estimation of environmental suitability for malaria vector development in Portugal. Remote Sens. Environ. 2014, 145, 116-130.

90. Dogan, H.M.; Cetin, I.; Egri, M. Spatiotemporal change and ecological modelling of malaria in Turkey by means of geographic information systems. Trans. R. Soc. Trop. Med. Hyg. 2010, 104, 726-732.

91. Sainz-Elipe, S.; Latorre, J.M.; Escosa, R.; Masià, M.; Fuentes, M.V.; Mas-Coma, S.; Bargues, M.D. Malaria resurgence risk in southern Europe: Climate assessment in an historically endemic area of rice fields at the Mediterranean shore of Spain. Malar. J. 2010, 9, 221.

92. Schröder, W.; Schmidt, G. Mapping the potential temperature-dependent tertian malaria transmission within the ecoregions of Lower Saxony (Germany). Int. J. Med. Microbiol. 2008, 298, 38-49.

93. Anis, E.; Grotto, I.; Mendelson, E.; Bin, H.; Orshan, L.; Gandacu, D.; Warshavsky, B.; Shinar, E.; Slater, P.E.; Lev, B. West Nile fever in Israel: The reemergence of an endemic disease. J. Infect. 2014, 68, 170-175.

94. Bakonyi, T.; Ferenczi, E.; Erdélyi, K.; Kutasi, O.; Csörgő, T.; Seidel, B.; Weissenböck, H.; Brugger, K.; Bán, E.; Nowotny, N. Explosive spread of a neuroinvasive lineage 2 West Nile virus in Central Europe, 2008/2009. Vet. Microbiol. 2013, 165, 61-70.

95. WHO. Regional Office for Europe Information Leaflet: West Nile Virus in the WHO European Region (English); WHO: Geneva, Switzerland, 2015.

96. Rezza, G.; Nicoletti, L.; Angelini, R.; Romi, R.; Finarelli, A.C.; Panning, M.; Cordioli, P.; Fortuna, C.; Boros, S.; Magurano, F.; et al. Infection with chikungunya virus in Italy: An outbreak in a temperate region. Lancet 2007, 370, 1840-1846.

97. WHO. Regional Office for Europe Information Leaflet: Chikungunya in the WHO European Region (English); WHO: Geneva, Switzerland, 2015.

98. Fischer, D.; Moeller, P.; Thomas, S.M.; Naucke, T.J.; Beierkuhnlein, C. Combining climatic projections and dispersal ability: A method for estimating the responses of sandfly vector species to climate change. PLoS Negl. Trop. Dis. 2011, 5, e1407.

99. Caminade, C.; Medlock, J.; Ducheyne, E.; McIntyre, K.; Leach, S.; Baylis, M.; Morse, A. Suitability of European climate for the Asian tiger mosquito Aedes albopictus: Recent trends and future scenarios. J. R. Soc. Interface 2012, 9, 2708-2717.

100. Rogers, D.J.; Suk, J.E.; Semenza, J.C. Using global maps to predict the risk of dengue in Europe. Acta Trop. 2014, 129, 1-14.

101. Seyler, T.; Grandesso, F.; Strat, Y.L.; Tarantola, A.; Depoortere, E. Assessing the risk of importing dengue and chikungunya viruses to the European Union. Epidemics 2009, 1, 175-184. 
102. Lourenço, J.; Recker, M. The 2012 Madeira dengue dutbreak: Epidemiological determinants and future epidemic potential. PLoS Negl. Trop. Dis. 2014, 8, e3083.

103. Bouzid, M.; Colón-González, F.; Lung, T.; Lake, I.; Hunter, P. Climate change and the emergence of vector-borne diseases in Europe: Case study of dengue fever. BMC Public Health 2014, 14, 781.

104. Sudre, B.; Rakotoarivony, L.M.; Vas, J. Mission Report: Dengue outbreak in Madeira, Portugal; European Centre for Disease Prevention and Control: Stockholm, Sweden, 2012.

105. Marchand, E.; Prat, C.; Jeannin, C.; Lafont, E.; Bergmann, T.; Flusin, O.; Rizzi, J.; Roux, N.; Busso, V.; Deniau, J.; et al. Autochthonous case of dengue in France, October 2013. Eurosurveillance 2013, 18, doi:10.2807/1560-7917.ES2013.18.50.20661.

106. WHO. Regional Office for Europe Information Leaflet: Dengue in the WHO European Region (English); WHO: Geneva, Switzerland, 2015.

107. Fischer, D.; Thomas, S.M.; Niemitz, F.; Reineking, B.; Beierkuhnlein, C. Projection of climatic suitability for Aedes albopictus Skuse (Culicidae) in Europe under climate change conditions. Glob. Planet. Chang. 2011, 78, 54-64.

108. Yilmaz, G.R.; Buzgan, T.; Irmak, H.; Safran, A.; Uzun, R.; Cevik, M.A.; Torunoglu, M.A. The epidemiology of Crimean-Congo hemorrhagic fever in Turkey, 2002-2007. Int. J. Infect. Dis. 2009, 13, 380-386.

109. Atkinson, B.; Chamberlain, J.; Jameson, L.J.; Logue, C.H.; Lewis, J.; Belobrova, E.A.; Valikhodzhaeva, M.; Mullojonova, M.; Tishkova, F.H.; Hewson, R. Identification and analysis of Crimean-Congo hemorrhagic fever virus from human sera in Tajikistan. Int. J. Infect. Dis. 2013, 17, e1031-e1037.

110. Altobelli, A.; Boemo, B.; Mignozzi, K.; Bandi, M.; Floris, R.; Menardi, G.; Cinco, M. Spatial Lyme borreliosis risk assessment in north-eastern Italy. Int. J. Med. Microbiol. 2008, 298, 125-128.

111. Barrios, J.M.; Verstraeten, W.W.; Maes, P.; Clement, J.; Aerts, J.M.; Farifteh, J.; Lagrou, K.; van Ranst, M.; Coppin, P. Remotely sensed vegetation moisture as explanatory variable of Lyme borreliosis incidence. Int. J. Appl. Earth Obs. Geoinf. 2012, 18, 1-12.

112. Jaenson, T.G. T.; Jaenson, D.G. E.; Eisen, L.; Petersson, E.; Lindgren, E. Changes in the geographical distribution and abundance of the tick Ixodes ricinus during the past 30 years in Sweden. Parasit. Vectors 2012, 5, 8.

113. Walder, G.; Falkensammer, B.; Heinz, F.X.; Holzmann, H.; Dierich, M.P.; Würzner, R. Tick-borne encephalitis in the Tyrol (Austria): Changes in incidence and endemicity 2000-2006. Int. J. Med. Microbiol. 2008, 298, 88-93.

114. Avxentev, N.; Avxentyeva, M.; Platonov, A.; Kolyasnikova, N.; Gridneva, K.; Dolgin, V.; Titkov, A.; Derkach, E. V Evaluating economic burden of tick-borne encephalitis. Evidence from Russia. Value Health 2013, 16, A347-A348.

115. Briggs, B.J.; Atkinson, B.; Czechowski, D.M.; Larsen, P.A.; Meeks, H.N.; Carrera, J.P.; Duplechin, R.M.; Hewson, R.; Junushov, A.T.; Gavrilova, O.N.; et al. Tick-borne encephalitis virus, Kyrgyzstan. Emerg. Infect. Dis. 2011, 17, 876-879.

116. Brinkley, C.; Nolskog, P.; Golovljova, I.; Lundkvist, Å.; Bergström, T. Tick-borne encephalitis virus natural foci emerge in western Sweden. Int. J. Med. Microbiol. 2008, 298, 73-80. 
117. Daniel, M.; Danielova, V.; Kriz, B.; Jirsa, A.; Nozicka, J.; Nozicka, J. Shift of the tick ixodes ricinus and tick-borne encephalitis to higher altitudes in Central Europe. Eur. J. Clin. Microbiol. Infect. Dis. 2003, 22, 327-328.

118. Daniel, M.; Křŕž, B.; Danielová, V.; Beneš, Č. Sudden increase in tick-borne encephalitis cases in the Czech Republic, 2006. Int. J. Med. Microbiol. 2008, 298, 81-87.

119. Daniel, M.; Schwarzova, L.; Materna, J.; Rudenko, N.; Golovchenko, M.; Holubova, J.; Grubhoffer, L.; Kilian, P. Integration of a tick-borne encephalitis virus and borrelia burgdorferi sensu lato into mountain ecosystems, following a shift in the altitudinal limit of distribution of their vector, Ixodes ricinus (Krkonose Mountains, Czech Republic). Vector Borne Zoonotic Dis. 2010, 10, 223-230.

120. Lacey, J. Climate change and Norman Daniels' theory of just health: An essay on basic needs. Med. Health Care Philos. 2012, 15, 3-14.

121. Balci, E.; Borlu, A.; Kilic, A.U.; Demiraslan, H.; Oksuzkaya, A.; Doganay, M. Tularemia outbreaks in Kayseri, Turkey: An evaluation of the effect of climate change and climate variability on tularemia outbreaks. J. Infect. Public Health 2014, 7, 125-132.

122. Gray, J.S. Ixodes ricinus seasonal activity: Implications of global warming indicated by revisiting tick and weather data. Int. J. Med. Microbiol. 2008, 298, 19-24.

123. Knap, N.; Durmiši, E.; Saksida, A.; Korva, M.; Petrovec, M.; Avšič-Županc, T. Influence of climatic factors on dynamics of questing Ixodes ricinus ticks in Slovenia. Vet. Parasitol. 2009, 164, 275-281.

124. Široký, P.; Kubelová, M.; Bednář, M.; Modrý, D.; Hubálek, Z.; Tkadlec, E.; Siroký, P. The distribution and spreading pattern of Dermacentor reticulatus over its threshold area in the Czech Republic - How much is range of this vector expanding? Vet. Parasitol. 2011, 183, 130-135.

125. Jaenson, T.G. T.T.; Lindgren, E. The range of Ixodes ricinus and the risk of contracting Lyme borreliosis will increase northwards when the vegetation period becomes longer. Ticks Tick Borne Dis. 2011, 2, 44-49.

126. Barrios, J.M.; Verstraeten, W.W.; Maes, P.; Aerts, J.M.; Farifteh, J.; Coppin, P. Seasonal vegetation variables and their impact on the spatio-temporal patterns of nephropathia epidemica and Lyme borreliosis in Belgium. Appl. Geogr. 2013, 45, 230-240.

127. Danielová, V.; Schwarzová, L.; Materna, J.; Daniel, M.; Metelka, L.; Holubová, J.; Kř́̌ž, B. Tick-borne encephalitis virus expansion to higher altitudes correlated with climate warming. Int. J. Med. Microbiol. 2008, 298, 68-72.

128. Daniel, M.; Kříž , B.; Valter, J.; Kott, I.; Danielová, V. The influence of meteorological conditions of the preceding winter on the incidences of tick-borne encephalitis and Lyme borreliosis in the Czech Republic. Int. J. Med. Microbiol. 2008, 298, 60-67.

129. Kausrud, K.L.; Viljugrein, H.; Frigessi, A.; Begon, M.; Davis, S.; Leirs, H.; Dubyanskiy, V.; Stenseth, N. Climatically driven synchrony of gerbil populations allows large-scale plague outbreaks. Proc. R. Soc. 2007, 274, 1963-1969.

130. Kausrud, K.L.; Begon, M.; Ari, T.B.; Viljugrein, H.; Esper, J.; Büntgen, U.; Leirs, H.; Junge, C.; Yang, B.; Yang, M.; et al. Modeling the epidemiological history of plague in Central Asia: Palaeoclimatic forcing on a disease system over the past millennium. BMC Biol. 2010, 8, 112. 
131. ECDC "Leptospirosis." European Centre for Disease Prevention and Control, 2015. Available online: http://www.ecdc.europa.eu/en/healthtopics/leptospirosis/pages/index.aspx (accessed on 11 November 2015).

132. Lau, C.L.; Smythe, L.D.; Craig, S.B.; Weinstein, P. Climate change, flooding, urbanisation and leptospirosis: Fuelling the fire? Trans. R. Soc. Trop. Med. Hyg. 2010, 104, 631-638.

133. Marrama-Rakotoarivony, L.; Sudre, B.; van Bortel, W.; Warns-Petit, E.; Zeller, H. Annual Epidemiological Report 2014: Emerging and Vector-Borne Diseases; ECDC: Stockholm, Sweden, 2014.

134. Heyman, P.; Ceianu, C.; Christova, I.; Tordo, N.; Beersma, M.; Joao Alves, M.; Lundkvist, A.; Hukic, M.; Papa, A.; Tenorio, A.; et al. A five-year perspective on the situation of haemorrhagic fever with renal syndrome and status of the hantavirus reservoirs in Europe, 2005-2010. Eurosurveillance 2011, 16, 19961.

135. Kovats, R.S.; Edwards, S.J.; Hajat, S.; Armstrong, B.G.; Ebi, K.L.; Menne, B. The effect of temperature on food poisoning: A time-series analysis of salmonellosis in ten European countries. Epidemiol. Infect. 2004, 132, 443-453.

136. Grjibovski, A.; Kosbayeva, A.; Menne, B. The effect of ambient air temperature and precipitation on monthly counts of salmonellosis in four regions of Kazakhstan, Central Asia, in 2000-2010. Epidemiol. Infect. 2014, 142, 608-615.

137. Jore, S.; Viljugrein, H.; Brun, E.; Heier, B.T.; Borck, B.; Ethelberg, S.; Hakkinen, M.; Kuusi, M.; Reiersen, J.; Hansson, I.; et al. Trends in Campylobacter incidence in broilers and humans in six European countries, 1997-2007. Prev. Vet. Med. 2010, 93, 33-41.

138. ECDC. Assessing the Potential Impacts of Climate Change on Food-and Waterborne Diseases in Europe; ECDC: Stockholm, Sweden, 2012; p. 19.

139. Nichols, G.; Lane, C.; Asgari, N.; Verlander, N.; Charlett, A.; Charlette, A. Rainfall and outbreaks of drinking water related disease and in England and Wales. J. Water Health 2009, 7, 1-8.

140. Beauté, J.; Zucs, P.; de Jong, B. Legionnaires disease in Europe, 2009-2010. Eurosurveillance 2013, 18, 20417.

141. Paz, S.; Bisharat, N.; Paz, E.; Kidar, O.; Cohen, D. Climate change and the emergence of Vibrio vulnificus disease in Israel. Env. Res 2007, 103, 390-396.

142. Gallina, N.; Anneville, O.; Beniston, M. Impacts of extreme air temperatures on cyanobacteria in five deep peri-Alpine lakes. J. Limnol. 2011, 70, 186-196.

143. Tryland, I.; Myrmel, M.; Østensvik, Ø.; Wennberg, A.C.; Robertson, L.J. Impact of rainfall on the hygienic quality of blue mussels and water in urban areas in the Inner Oslofjord, Norway. Mar. Pollut. Bull. 2014, 85, 42-49.

144. Van Asselt, E.D.; Azambuja, W.; Moretti, A.; Kastelein, P.; de Rijk, T.C.; Stratakou, I.; van der Fels-Klerx, H.J. A Dutch field survey on fungal infection and mycotoxin concentrations in maize. Food Addit. Contam. Part A Chem. Anal. Control Exp. Risk Assess. 2012, 29, 1556-1565.

145. WHO. Economic Cost of the Health Impact of Air Pollution in Europe: Clean Air, Health and Wealth; World Health Organization: Geneva, Switzerland, 2015.

146. Meleux, F.; Solmon, F.; Giorgi, F. Increase in summer European ozone amounts due to climate change. Atmos. Environ. 2007, 41, 7577-7587. 
147. Orru, H.; Andersson, C.; Ebi, K.L.; Langner, J.; Aström, C.; Forsberg, B. Impact of climate change on ozone-related mortality and morbidity in Europe. Eur. Respir. J. 2013, 41, 285-294.

148. Katsouyanni, K.; Analitis, A. Investigating the synergistic effects between meteorological variables and air pollutants: Results from the European PHEWE, EUROHEAT and CIRCE projects. Epidemiology 2009, 20, S264-S264.

149. Analitis, A.; Katsouyanni, K.; Biggeri, A.; Baccini, M.; McGregor, G.; Michelozzi, P. Temperature effects on mortality: Potential confounding by air pollution and possible interactions within the PHEWE project. Epidemiology 2008, 19, S214.

150. Lagravinese, R.; Moscone, F.; Tosetti, E.; Lee, H. The impact of air pollution on hospital admissions: Evidence from Italy. Reg. Sci. Urban Econ. 2014, 49, 278-285.

151. Almeida, S.P. de; Casimiro, E.; Calheiros, J.; de Almeida, S.P.; Casimiro, E.; Calheiros, J. Short-term association between exposure to ozone and mortality in Oporto, Portugal. Environ. Res. 2011, 111, 406-410.

152. Bejot, Y.; Henrotin, J.B.; Osseby, G.V.; Zeller, M.; Cottin, Y.; Giroud, M. Impact of ozone air pollution on ischemic cerebral and cardiac events in Dijon, France. Arch. Cardiovasc. Dis. Suppl. 2011, 3, 93.

153. Kalantzi, E.G.; Makris, D.; Duquenne, M.N.; Kaklamani, S.; Stapountzis, H.; Gourgoulianis, K.I. Air pollutants and morbidity of cardiopulmonary diseases in a semi-urban Greek peninsula. Atmos. Environ. 2011, 45, 7121-7126.

154. De Sario, M.; Katsouyanni, K.; Michelozzi, P. Climate change, extreme weather events, air pollution and respiratory health in Europe. Eur. Respir. J. 2013, 42, 826-843.

155. Jankovic, S.; Denic, L.M.; Milic, N.; Spiric, V.T.; Gledovic, Z.; Marinkovic, J. The effects of air pollution on the respiratory and cardiovascular system: A systematic review. Med. Data 2011, $3,57-62$.

156. Faustini, A.; Stafoggia, M.; Berti, G.; Bisanti, L.; Chiusolo, M.; Cernigliaro, A.; Mallone, S.; Primerano, R.; Scarnato, C.; Simonato, L.; et al. The relationship between ambient particulate matter and respiratory mortality: A multi-city study in Italy. Eur. Respir. J. 2011, 38, 538-547.

157. Maté, T.; Guaita, R.; Pichiule, M.; Linares, C.; Díaz, J. Short-term effect of fine particulate matter (PM2.5) on daily mortality due to diseases of the circulatory system in Madrid (Spain). Sci. Total Environ. 2010, 408, 5750-5757.

158. Neuberger, M.; Rabczenko, D.; Moshammer, H. Extended effects of air pollution on cardiopulmonary mortality in Vienna. Atmos. Environ. 2007, 41, 8549-8556.

159. Nuvolone, D.; Balzi, D.; Pepe, P.; Chini, M.; Scala, D.; Giovannini, F.; Cipriani, F.; Barchielli, A. Ozone short-term exposure and acute coronary events: A multicities study in Tuscany (Italy). Environ. Res. 2013, 126, 17-23.

160. Ghosh, R.; Joad, J.; Benes, I.; Dostal, M.; Sram, R.J.; Hertz-Picciotto, I. Ambient nitrogen oxides exposure and early childhood respiratory illnesses. Environ. Int. 2012, 39, 96-102.

161. Altuğ, H.; Gaga, E.O.; Döğeroğlu, T.; Brunekreef, B.; Hoek, G.; van Doorn, W. Effects of ambient air pollution on respiratory tract complaints and airway inflammation in primary school children. Sci. Total Environ. 2014, 479-480, 201-209.

162. Coneus, K.; Spiess, C.K. Pollution exposure and child health: Evidence for infants and toddlers in Germany. J. Health Econ. 2012, 31, 180-196. 
163. Pedersen, M.; Giorgis-Allemand, L.; Bernard, C.; Aguilera, I.; Andersen, A.M.; Ballester, F.; Beelen, R.M.; Chatzi, L.; Cirach, M.; Danileviciute, A.; et al. Ambient air pollution and low birthweight: A European cohort study (ESCAPE). Lancet Respir. Med. 2013, 1, 695-704.

164. Amann, M.; Klimont, Z.; Wagner, F. Regional and global emissions of air pollutants: Recent trends and future scenarios. Annu. Rev. Environ. Resour. 2013, 38, 31-55.

165. Scheinhardt, S.; Spindler, G.; Leise, S.; Müller, K.; Iinuma, Y.; Zimmermann, F.; Matschullat, J.; Herrmann, H. Comprehensive chemical characterisation of size-segregated $\mathrm{PM}_{10}$ in Dresden and estimation of changes due to global warming. Atmos. Environ. 2013, 75, 365-373.

166. Makkonen, U.; Hellén, H.; Anttila, P.; Ferm, M. Size distribution and chemical composition of airborne particles in south-eastern Finland during different seasons and wildfire episodes in 2006. Sci. Total Environ. 2010, 408, 644-651.

167. Fattore, E.; Paiano, V.; Borgini, A.; Tittarelli, A.; Bertoldi, M.; Crosignani, P.; Fanelli, R. Human health risk in relation to air quality in two municipalities in an industrialized area of Northern Italy. Environ. Res. 2011, 111, 1321-1327.

168. Halonen, J.I.; Lanki, T.; Yli-Tuomi, T.; Kulmala, M.; Tiittanen, P.; Pekkanen, J. Urban air pollution, and asthma and COPD hospital emergency room visits. Thorax 2008, 63, 635-641.

169. Huttunen, K.; Siponen, T.; Salonen, I.; Yli-Tuomi, T.; Aurela, M.; Dufva, H.; Hillamo, R.; Linkola, E.; Pekkanen, J.; Pennanen, A.; et al. Low-level exposure to ambient particulate matter is associated with systemic inflammation in ischemic heart disease patients. Environ. Res. 2012, 116, 44-51.

170. Koton, S.; Molshatzki, N.; Yuval; Myers, V.; Broday, D.M.; Drory, Y.; Steinberg, D.M.; Gerber, Y. Cumulative exposure to particulate matter air pollution and long-term post-myocardial infarction outcomes. Prev. Med. (Baltim.) 2013, 57, 339-344.

171. Leitte, A.M.; Petrescu, C.; Franck, U.; Richter, M.; Suciu, O.; Ionovici, R.; Herbarth, O.; Schlink, U. Respiratory health, effects of ambient air pollution and its modification by air humidity in Drobeta-Turnu Severin, Romania. Sci. Total Environ. 2009, 407, 4004-4011.

172. Linares, C.; Díaz, J. Short-term effect of concentrations of fine particulate matter on hospital admissions due to cardiovascular and respiratory causes among the over-75 age group in Madrid, Spain. Public Health 2010, 124, 28-36.

173. Naess, O.; Nafstad, P.; Aamodt, G.; Claussen, B.; Rosland, P. Relation between concentration of air pollution and cause-specific mortality: Four-year exposures to nitrogen dioxide and particulate matter pollutants in 470 neighborhoods in Oslo, Norway. Am. J. Epidemiol. 2007, 165, 435-443.

174. Nuvolone, D.; Balzi, D.; Chini, M.; Scala, D.; Giovannini, F.; Barchielli, A. Short-term association between ambient air pollution and risk of hospitalization for acute myocardial infarction: Results of the cardiovascular risk and air pollution in Tuscany (RISCAT) study. Am. J. Epidemiol. 2011, 174, 63-71.

175. Wang, M.; Beelen, R.; Stafoggia, M.; Raaschou-Nielsen, O.; Andersen, Z.J.; Hoffmann, B.; Fischer, P.; Houthuijs, D.; Nieuwenhuijsen, M.; Weinmayr, G.; et al. Long-term exposure to elemental constituents of particulate matter and cardiovascular mortality in 19 European cohorts: Results from the ESCAPE and TRANSPHORM projects. Environ. Int. 2014, 66, 97-106. 
176. Zauli Sajani, S.; Alessandrini, E.; Marchesi, S.; Lauriola, P. Are day-to-day variations of airborne particles associated with emergency ambulance dispatches? Int. J. Occup. Environ. Health 2014, 20, 71-76.

177. Shea, K.; Truckner, R.; Weber, R.; Peden, D. Climate change and allergic disease. Clin. Rev. Allergy Immunol. 2008, 122, 443-453.

178. Bielory, L.; Lyons, K.; Goldberg, R. Climate change and allergic disease. Curr. Allergy Asthma Rep. 2012, 12, 485-494.

179. Weber, R. Impact of climate change on aeroallergens. Ann. Allergy Asthma Immunol. 2012, 108, 294-299.

180. Cecchi, L.; D’Amato, G.; Ayres, J.G.; Galan, C.; Forastiere, F.; Forsberg, B.; Gerritsen, J.; Nunes, C.; Behrendt, H.; Akdis, C.; et al. Projections of the effects of climate change on allergic asthma: The contribution of aerobiology. Allergy 2010, 65, 1073-1081.

181. D’Amato, G.; Cecchi, L.; D’Amato, M.; Annesi-Maesano, I. Climate change and respiratory diseases. Eur. Respir. Rev. 2014, 23, 161-169.

182. Zuberbier, T.; Lotvall, J.; Simoens, S.; Subramanian, S.; Church, M. Economic burden of inadequate management of allergic diseases in the European Union: A GA2LEN review. Eur. J. Allergy Clin. Immunol. 2014, 69, 1275-1279.

183. Tosca, M.A.; Ruffoni, S.; Canonica, G.W.; Ciprandi, G. Asthma exacerbation in children: Relationship among pollens, weather, and air pollution. Allergol. Immunopathol. 2014, 42, 362-368.

184. Matyasovszky, I.; Makra, L.; Bálint, B.; Guba, Z.; Sümeghy, Z. Multivariate analysis of respiratory problems and their connection with meteorological parameters and the main biological and chemical air pollutants. Atmos. Environ. 2011, 45, 4152-4159.

185. Ziello, C.; Sparks, T.H.; Estrella, N.; Belmonte, J.; Bergmann, K.C.; Bucher, E.; Brighetti, M.A.; Damialis, A.; Detandt, M.; Galán, C.; et al. Changes to Airborne Pollen Counts across Europe. PLoS ONE 2012, 7, e34076.

186. Grinn-Gofroń, A.; Rapiejko, P. Occurrence of Cladosporium spp. and Alternaria spp. spores in Western, Northern and Central-Eastern Poland in 2004-2006 and relation to some meteorological factors. Atmos. Res. 2009, 93, 747-758.

187. Makra, L.; Matyasovszky, I.; Deák, Á.J. Trends in the characteristics of allergenic pollen circulation in central Europe based on the example of Szeged, Hungary. Atmos. Environ. 2011, 45, 6010-6018.

188. Cariñanos, P.; Alcázar, P.; Galán, C.; Domínguez, E. Environmental behaviour of airborne Amaranthaceae pollen in the southern part of the Iberian Peninsula, and its role in future climate scenarios. Sci. Total Environ. 2014, 470-471, 480-487.

189. Deák, Á.J.; Makra, L.; Matyasovszky, I.; Csépe, Z.; Muladi, B. Climate sensitivity of allergenic taxa in Central Europe associated with new climate change related forces. Sci. Total Environ. 2013, 442, 36-47.

190. Damialis, A.; Halley, J.M.; Gioulekas, D.; Vokou, D. Long-term trends in atmospheric pollen levels in the city of Thessaloniki, Greece. Atmos. Environ. 2007, 41, 7011-7021.

191. Sousa, S.I. V; Martins, F.G.; Pereira, M.C.; Alvim-Ferraz, M.C. M.; Ribeiro, H.; Oliveira, M.; Abreu, I. Influence of atmospheric ozone, $\mathrm{PM}_{10}$ and meteorological factors on the concentration of airborne pollen and fungal spores. Atmos. Environ. 2008, 42, 7452-7464. 
192. Ridolo, E.; Albertini, R.; Giordano, D.; Soliani, L.; Usberti, I.; Dall’Aglio, P. Respiratory Allergy and Airborne Pollen Concentrations in Italy from 1992 to 2004. J. Allergy Clin. Immunol. 2007, 119, S100.

193. Bedada, G.B.; Heinrich, J.; Götschi, T.; Downs, S.H.; Forsberg, B.; Jarvis, D.; Luczynska, C.; Soon, A.; Sunyer, J.; Toren, K.; et al. Urban background particulate matter and allergic sensitization in adults of ECRHS II. Int. J. Hyg. Environ. Health 2007, 210, 691-700.

194. Feo Brito, F.; Mur Gimeno, P.; Martinez, C.; Tobias, A.; Suarez, L.; Guerra, F.; Borja, J.M.; Alonso, A.M. Air pollution and seasonal asthma during the pollen season. A cohort study in Puertollano and Ciudad Real (Spain). Allergy 2007, 62, 1152-1157.

195. Albertine, J.M.; Manning, W.J.; Dacosta, M.; Stinson, K.A.; Muilenberg, M.L.; Rogers, C.A. Projected carbon dioxide to increase grass pollen and allergen exposure despite higher ozone levels. PLoS ONE 2014, 9, e111712.

196. Singer, B.; Ziska, L.; Frenz, D.; Gebhard, D.; Straka, J. Increasing Amb a 1 content in common ragweed (Ambrosia artemisiifolia) pollen as a function of rising atmospheric $\mathrm{CO}_{2}$ concentration. Funct. Plant Biol. 2005, 32, 667-670.

197. El Kelish, A.; Zhao, F.; Heller, W.; Durner, J.; Winkler, J.B.; Behrendt, H.; Traidl-Hoffmann, C.; Horres, R.; Pfeifer, M.; Frank, U.; et al. Ragweed (Ambrosia artemisiifolia) pollen allergenicity: SuperSAGE transcriptomic analysis upon elevated $\mathrm{CO}_{2}$ and drought stress. BMC Plant Biol. 2014, 14, 176.

198. Arnedo-Pena, A.; García-Marcos, L.; Urueña, I.C.; Monge, R.B.; Suárez-Varela, M.M.; Canflanca, I.M.; Garrido, J.B.; Quirós, A.B.; López-Silvarrey Varela, Á.; Hernández, G.G.; et al. Air pollution and recent symptoms of asthma, allergic rhinitis, and atopic eczema in schoolchildren aged between 6 and 7 Years. Arch. Bronconeumol. (Engl. Ed.) 2009, 45, 224-229.

199. Makra, L.; Matyasovszky, I.; Bálint, B. Association of allergic asthma emergency room visits with the main biological and chemical air pollutants. Sci. Total Environ. 2012, 432, 288-296.

200. Ayres-Sampaio, D.; Teodoro, A.C.; Sillero, N.; Santos, C.; Fonseca, J.; Freitas, A. An investigation of the environmental determinants of asthma hospitalizations: An applied spatial approach. Appl. Geogr. 2014, 47, 10-19.

201. Berna Dursun, A.; Çelik, G.E.; Alan, S.; Münevver Pinar, N.; Mungan, D.; Misirligil, Z. Regional pollen load: Effect on sensitisation and clinical presentation of seasonal allergic rhinitis in patients living in Ankara, Turkey. Allergol. Immunopathol. (Madr.) 2008, 36, 371-378.

202. Cirera, L.; García-Marcos, L.; Giménez, J.; Moreno-Grau, S.; Tobías, A.; Pérez-Fernández, V.; Elvira-Rendeles, B.; Guillén, J.J.; Navarro, C. Daily effects of air pollutants and pollen types on asthma and COPD hospital emergency visits in the industrial and Mediterranean Spanish city of Cartagena. Allergol. Immunopathol. (Madr.) 2012, 40, 231-237.

203. Ruffoni, S.; Passalacqua, G.; Ricciardolo, F.; Furgani, A.; Negrini, A.C.; De Amici, M.; Ciprandi, G. A 10-year survey on asthma exacerbations: Relationships among emergency medicine calls, pollens, weather, and air pollution. Rev. Fr. Allergol. 2013, 53, 569-575.

(C) 2015 by the authors; licensee MDPI, Basel, Switzerland. This article is an open access article distributed under the terms and conditions of the Creative Commons Attribution license (http://creativecommons.org/licenses/by/4.0/). 